Original Article

\title{
DEVELOPMENT, FORMULATION AND EVALUATION OF A BILAYER GASTRIC RETENTIVE FLOATING TABLETS OF RANITIDINE HCL AND CLARITHROMYCIN USING NATURAL POLYMERS
}

\author{
SARIPILLI RAJESWARI ${ }^{*}$, SRAVYA KUDAMALA ${ }^{2}$, KOLLAPALLI VENKATA RAMANA MURTHY ${ }^{2}$ \\ ${ }^{1}$ Maharajah's College of Pharmacy, Phool Baugh, Vizianagaram (Andhra Pradesh), ${ }^{2}$ A. U. College of Pharmaceutical Sciences, Andhra \\ University, Visakhapatnam \\ Email: rajeswarimalli@gmail.com
}

Received: 27 May 2017 Revised and Accepted: 22 Jul 2017

\begin{abstract}
Objective: Bilayer gastric retentive floating tablets (BGRFT) with ranitidine $\mathrm{HCl}$ and clarithromycin using natural gums have been developed to prolong the gastric residence time and increase drug bioavailability. Literature review revealed no published studies on the present study.

Methods: Immediate release (IR) layer prepared by using different diluents and super disintegrants like sodium starch glycolate, crosscarmellose sodium and crospovidone. Controlled released (CR) layer prepared by using neem gum, damar gum and copal gum. Prepared tablets were evaluated for in vivo and in vitro buoyancy, in vitro dissolution studies and fourier transformation-infrared spectroscopy (FTIR). Drug release was evaluated with zero and first order for release kinetics, Higuchi, Hixson-Crowell erosion models for release mechanism.
\end{abstract}

Results: Prepared IR layer followed first order rate kinetics and CR layer followed zero order rate kinetics with non-Fickian diffusion mechanism. BGRFT also showed similar results as that of the individual layer. Optimized formulations were characterized by FTIR studies and found no interactions between drug and polymer.

Conclusion: The results demonstrate the feasibility of the model in the development of BGRFT. BGRFT enhanced the drug release and finally the bioavailability of clarithromycin when compared with commercial tablet (Biomycin 250). The present study could establish the suitability of neem gum as CR polymer in the design of BGRFT.

Keywords: Ranitidine HCl, Clarithromycin, Super disintegrants, Neem gum, Damar gum, copal gum, Gastric retention, Immediate release, Controlled release, Bilayer floating tablet

(c) 2017 The Authors. Published by Innovare Academic Sciences Pvt Ltd. This is an open access article under the CC BY license (http://creativecommons.org/licenses/by/4.0/) DOI: http://dx.doi.org/10.22159/ijpps.2017v9i9.20290

\section{INTRODUCTION}

Gastric retention systems are such systems, which increase the gastric retention time of the dosage form at the stomach and upper parts of the small intestine and suitable for the drugs having site specific absorption from the above sites. The controlled release of the drug from these systems at the preferred absorption site optimizes delivery of the drug, maximizing its therapeutic benefits and reduces side effects by permitting a large portion of the drug to be absorbed before passing through the lower gastro intestinal tract. Many attempts like floating drug delivery systems, swelling and expanding systems, polymeric bioadhesive systems, modified shape systems, high density systems and other delayed gastric emptying devices have been made in recent years to provide a dosage form with a longer gastric retention time and therefore more efficient absorption [1].

Compared to these approaches, the gastric floating drug delivery system (GFDDS) developed has provided several advantages, as shown by the encouraging results reported earlier. Furthermore, the buoyancy action provided by the GFDDS seems to offer a greater safety for clinical uses than some of the above mentioned approaches. In fact, no adverse effects due to floating devices have been reported to date. GFDDS are also appropriate for drugs which are locally active to the gastric mucosa in the stomach, in particular case of antibiotic administration for Helicobacter pylori (H. Pylori) eradication in the treatment of peptic ulcer disease [2].

In the present investigation ranitidine $\mathrm{HCl}$ and clarithromycin were selected as model drugs for the development of bilayer gastro retentive floating tablets (BGRFT). Ranitidine $\mathrm{HCl}$ is used to reduce the acid secretion in the stomach, which in turn helps in stabilizing and enhancing the concentration of clarithromycin. Hence, the combination of ranitidine $\mathrm{HCl}$ and clarithromycin was selected.
Ranitidine $\mathrm{HCl}$ is a non selective beta-adrenergic receptor blocking agent prepared as an immediate release layer using lactose as a diluent and sodium starch glycolate as disintegrant. Clarithromycin is a macrolide antibiotic which is used in the treatment of $H$. Pylori infection. Clarithromycin controlled release tablets were prepared using natural polymers (neem gum, gum copal and gum damar) as release retarding polymers in the present investigation.

Based on previously published literature, applications of gastro retentive drug delivery system (GRDDS) may be suitable for the drugs insoluble in intestinal fluids. As discussed earlier, clarithromycin degrades in acid secretion, but its absorption window is in stomach and in presence of ranitidine $\mathrm{HCl}$ the bioavailability of clarithromycin is increased, which makes it suitable for BGRFT. Till now there were no reports found on neem gum used as a release retarding polymer [3-11]. Through this present investigation we have developed a BGRFT of ranitidine $\mathrm{HCl}$ and clarithromycin. In this study the applicability of neem gum, gum copal and gum damar as a release retarding agents for controlled release layer was seen.

\section{MATERIALS AND METHODS}

\section{Materials}

Ranitidine $\mathrm{HCl}$ and clarithromycin were provided by Dr Reddy's Laboratories Ltd (Hyderabad, India). Neem, copal and damar gum procured from Palaniappa Chettian Traders. (Chennia, India). All other reagents and chemicals were of analytical grade.

\section{Preparation of ranitidine $\mathrm{HCl}$ immediate release tablets}

All the ingredients sufficient for a batch of 100 tablets according to the formulae shown in table 1 and 2 were passed through sieve \#40 $(425 \mu \mathrm{m})$. All the ingredients were geometrically mixed to obtain a 
homogenous blend. Magnesium stearate and Aerosil, passed through sieve \#60 (250 $\mu \mathrm{m})$ were mixed with the powder blend for $3 \mathrm{~min}$ in poly bag. The flow properties of the final blend were found to be good so final blend was directly compressed into tablets on a 12-station rotary punching machine (M/s. Karnavati Engineering Ltd. India) using $9 \mathrm{~mm}$ round flat punches.

Table 1: Formulae of ranitidine $\mathrm{HCl}$ immediate release tablets with diluents

\begin{tabular}{|c|c|c|c|c|c|c|c|c|}
\hline Ingredients (mg) & FR1 & FR2 & FR3 & FR4 & FR5 & FR6 & FR7 & FR8 \\
\hline Ranitidine $\mathrm{HCl}$ & 150 & 150 & 150 & 150 & 150 & 150 & 150 & 150 \\
\hline MCC 101 & 40 & - & - & - & - & - & - & - \\
\hline MCC 102 & - & 40 & - & - & - & - & - & - \\
\hline Lactose & - & - & 40 & - & - & - & - & - \\
\hline Ac-di-sol & - & - & - & 40 & - & - & - & - \\
\hline Spray dried lactose & - & - & - & - & 40 & - & - & - \\
\hline SSG Primogel & - & - & - & - & - & 40 & - & - \\
\hline Di calcium phosphate & - & - & - & - & - & - & 40 & - \\
\hline Lycatab & - & - & - & - & - & - & - & 40 \\
\hline Magnesium stearate & 5 & 5 & 5 & 5 & 5 & 5 & 5 & 5 \\
\hline Talc & 5 & 5 & 5 & 5 & 5 & 5 & 5 & 5 \\
\hline Total weight (mg) & 200 & 200 & 200 & 200 & 200 & 200 & 200 & 200 \\
\hline
\end{tabular}

Table 2: Formulae of ranitidine $\mathrm{HCl}$ immediate release tablets with different super disintegrants ratios

\begin{tabular}{|c|c|c|c|c|c|c|c|c|c|}
\hline Ingredients(mg) & FR9 & FR10 & FR11 & FR12 & FR13 & FR14 & FR15 & FR16 & FR17 \\
\hline Ranitidine $\mathrm{HCl}$ & 150 & 150 & 150 & 150 & 150 & 150 & 150 & 150 & 150 \\
\hline Sodium starch glycolate & 4 & 6 & 8 & - & - & - & - & - & - \\
\hline Cross carmellose sodium & - & - & - & 4 & 6 & 8 & - & - & - \\
\hline Crospovidone & - & - & - & - & - & - & 4 & 6 & 8 \\
\hline Lactose & 38 & 36 & 34 & 38 & 36 & 34 & 38 & 36 & 34 \\
\hline Magnesium stearate & 4 & 4 & 4 & 4 & 4 & 4 & 4 & 4 & 4 \\
\hline Talc & 4 & 4 & 4 & 4 & 4 & 4 & 4 & 4 & 4 \\
\hline Total weight (mg) & 200 & 200 & 200 & 200 & 200 & 200 & 200 & 200 & 200 \\
\hline
\end{tabular}

Preparation of gastric retentive floating tablets of clarithromycin

All the formulations containing clarithromycin $250 \mathrm{mg}$ were prepared by direct compression using different proportions of drugpolymer ratio as given in table 3 to 5 . The respective powders, clarithromycin, release retarding polymers, a gas forming agent and diluent were passed separately through sieve \#40 $(425 \mu \mathrm{m})$. The batches were prepared according to the formulae, mixing of powders was carried out by passing through the sieve \#40. Blend was lubricated with magnesium stearate passed through sieve \#60 $(250 \mu \mathrm{m})$ for $3 \mathrm{~min}$ in poly bag. The lubricated blend was evaluated for flow characteristics as described in the previous section. The final blend was directly compressed into tablets on a 12-station rotary punching machine (M/s. Karnavati Engineering Ltd. India) using $12 \mathrm{~mm}$ round flat punches.

Table 3: Formulae of clarithromycin controlled release tablets of gastroretentive floating tablets with neem gum

\begin{tabular}{|c|c|c|c|c|c|c|c|c|}
\hline Ingredients (mg) & NG01 & NG02 & NG03 & NG04 & NG05 & NG06 & NG07 & NG08 \\
\hline Clarithromycin & 250 & 250 & 250 & 250 & 250 & 250 & 250 & 250 \\
\hline Neem gum & 100 & 125 & 150 & 175 & 200 & 150 & 175 & 200 \\
\hline Sodium bicarbonate & - & - & - & - & - & 62.4 & 62.4 & 62.4 \\
\hline MCC 102 & 105 & 80 & 55 & 30 & 5 & 52.6 & 27.6 & 2.6 \\
\hline Magnesium stearate & 5 & 5 & 5 & 5 & 5 & 5 & 5 & 5 \\
\hline Total weight (mg) & 460 & 460 & 460 & 460 & 460 & 520 & 520 & 520 \\
\hline
\end{tabular}

Table 4: Formulae of clarithromycin controlled release tablets and gastroretentive floating tablets with damar gum

\begin{tabular}{|c|c|c|c|c|c|c|c|c|}
\hline Ingredients (mg) & DM01 & DM02 & DM03 & DM04 & DM05 & DM06 & DM07 & DM08 \\
\hline Clarithromycin & 250 & 250 & 250 & 250 & 250 & 250 & 250 & 250 \\
\hline Damar gum & 100 & 125 & 150 & 175 & 200 & 200 & 225 & 250 \\
\hline Sodium bicarbonate & - & - & - & - & - & 74.4 & 74.4 & 74.4 \\
\hline Povidone K 30 & - & - & - & - & - & 31 & 31 & 31 \\
\hline MCC 102 & 105 & 80 & 55 & 30 & 5 & 58.6 & 33.6 & 8.6 \\
\hline Magnesium stearate & 5 & 5 & 5 & 5 & 5 & 6 & 6 & 6 \\
\hline Total weight (mg) & 460 & 460 & 460 & 460 & 460 & 620 & 620 & 620 \\
\hline
\end{tabular}

Table 5: Formulae of clarithromycin controlled release tablets and gastroretentive floating tablets with copal gum

\begin{tabular}{|c|c|c|c|c|c|c|c|c|}
\hline Ingredients (mg) & CP01 & CP02 & CP03 & CP04 & CP05 & CP06 & CP07 & CP08 \\
\hline Clarithromycin & 250 & 250 & 250 & 250 & 250 & 250 & 250 & 250 \\
\hline Copal gum & 100 & 125 & 150 & 175 & 200 & 200 & 225 & 250 \\
\hline Sodium bicarbonate & - & - & - & - & - & 74.4 & 74.4 & 74.4 \\
\hline Povidone K 30 & - & - & - & - & - & 31 & 31 & 31 \\
\hline MCC 102 & 105 & 80 & 55 & 30 & 5 & 58.6 & 33.6 & 8.6 \\
\hline Magnesium stearate & 5 & 5 & 5 & 5 & 5 & 6 & 6 & 6 \\
\hline Total weight (mg) & 460 & 460 & 460 & 460 & 460 & 620 & 620 & 620 \\
\hline
\end{tabular}




\section{Preparations of bilayer gastric retentive floating tablets}

Bilayer gastric retentive floating tablets (BGRFT) of ranitidine $\mathrm{HCl}$ (IR layer containing $150 \mathrm{mg}$ ) and clarithromycin (CR layer containing $250 \mathrm{mg}$ ) were prepared from the optimised formulations of each layer (optimised in immediate release and controlled release layer). The components of the individual layers of the BGRFT are given in table 6 . The two layers were compressed as a single tablet by direct compression technique. Initially the gastric floating layer part of clarithromycin was compressed with a total weight of 520 mg with low compression force to attain hardness of $3-4 \mathrm{~kg} / \mathrm{cm}^{2}$ and then the immediate release portion of the ranitidine $\mathrm{HCl}$ was added (200 mg) and bilayer gastric retentive floating tablets was compressed to attain a hardness of $4-6 \mathrm{~kg} / \mathrm{cm}^{2}$.

The tablets were compressed on a 12-station rotary punching machine (M/s. Karnavati Engineering Ltd. India) using $12 \mathrm{~mm}$ round flat punches. The total weight of the prepared BGRFT was $720 \mathrm{mg}$.

Table.6: Formula of bilayer gastric retentive floating tablets

\begin{tabular}{|c|c|c|}
\hline Ingredients (mg) & Ranitidine $\mathrm{HCl}$ immediate release layer & Clarithromycin controlled release layer \\
\hline Clarithromycin & - & 250 \\
\hline Neem gum & - & 175 \\
\hline Sodium bicarbonate & - & 62.4 \\
\hline MCC 102 & - & 27.6 \\
\hline Ranitidine $\mathrm{HCl}$ & 150 & - \\
\hline Sodium starch glycolate & 6 & - \\
\hline Lactose & 34 & - \\
\hline Magnesium stearate & 5 & 5 \\
\hline Talc & 5 & - \\
\hline Total weight (mg) & 200 & 520 \\
\hline
\end{tabular}

\section{Evaluation of tablets}

In vitro dissolution studies of ranitidine $\mathrm{HCl}$ immediate release tablets

In vitro release of ranitidine $\mathrm{HCl}$ from the prepared immediate release tablets were studied using USP dissolution test apparatus (LABINDIA, Disso 2000) employing the paddle stirrer (ApparatusII). $900 \mathrm{ml}$ of $0.1 \mathrm{~N} \mathrm{HCl}$ was used as dissolution medium maintained at a temperature of $37 \pm 0.5^{\circ} \mathrm{C}$ and the paddle was rotated at $50 \mathrm{rpm}$ [12]. Aliquots samples $(5 \mathrm{ml}$ each) were withdrawn at predetermined time intervals by means of a syringe fitted with 0.45 $\mu \mathrm{m}$ prefilter and immediately replaced with $5 \mathrm{ml}$ of fresh medium maintained at $37 \pm 0.5{ }^{\circ} \mathrm{C}$. Samples were filtered through $0.45 \mu \mathrm{m}$ millipore membrane filter and were suitably diluted with the dissolution medium wherever necessary and the absorbance of the samples was measured spectrophotometrically at $315 \mathrm{~nm}$ as per the UV method i.e. $50 \mathrm{mg}$ of ranitidine $\mathrm{HCl}$ was dissolved in sufficient amount of $0.1 \mathrm{~N} \mathrm{HCl}$ in a $50 \mathrm{ml}$ volumetric flask and the solution was made up to the mark with $0.1 \mathrm{~N} \mathrm{HCl}$ to prepare the stock solution [13]. From the stock solution, a series of dilutions were prepared to get $50,75,100,150,200$ and $250 \mu \mathrm{g} / \mathrm{ml}$ by using $0.1 \mathrm{~N} \mathrm{HCl}$. The absorbance of these solutions was measured against $0.1 \mathrm{~N} \mathrm{HCl}$ as blank in UV spectrophotometer (Model AX120, M/s. Shimadzu Corporation, Japan) at $315 \mathrm{~nm}$. All the estimations were done in triplicate and average values are reported.

\section{In vitro buoyancy studies}

The floating characteristics of all the prepared gastroretentive floating tablets of clarithromycin was determined by floating lag time (FLT) and total floating time (TFT).

\section{Floating lag time}

FLT of all the prepared formulations was measured by placing the tablets in a $250 \mathrm{ml}$ glass beaker containing $200 \mathrm{ml}$ of $0.1 \mathrm{~N} \mathrm{HCl}$. The time required for the tablet to rise to the surface and float was determined as floating lag time. This FLT was due to the time taken for the reaction between sodium bicarbonate and gastric fluids, which produced effervescence for the floating of the tablet. All the prepared formulations floated immediately after they were placed in the beaker.

\section{Total floating time}

TFT of all formulations was more than $24 \mathrm{~h}$. The tablets were placed in a $200 \mathrm{ml}$ glass beaker containing $0.1 \mathrm{~N} \mathrm{HCl}$ and the time was noted until the tablets disintegrate. The time interval between the introduction of the tablet and its floating to the top of dissolution medium was taken as FLT and the duration of system floatation was taken as TFT [14].
In vitro dissolution studies of both controlled release and gastric floating tablets of clarithromycin

In vitro release of clarithromycin from the prepared gastro retentive floating tablets (GFT) was studied using apparatus II (Disso 2000, M/s Lab India, Mumbai). The dissolution studies were conducted at a 50 rpm speed, using $500 \mathrm{ml}$ of $0.1 \mathrm{~N} \mathrm{HCl}$ solution as dissolution medium $[15,16]$. A sample of $5 \mathrm{ml}$ was withdrawn by means of a syringe fitted with a prefilter at appropriate time intervals and immediately replaced with $5 \mathrm{ml}$ of fresh medium maintained at $37 \pm 0.5^{\circ} \mathrm{C}$ so as to maintain constant volume. Samples were filtered through $0.45 \mu \mathrm{m}$ millipore membrane filter and analysed spectrophotometrically at 271 $\mathrm{nm}$ as per the UV method i.e. $50 \mathrm{mg}$ of clarithromycin was dissolved in sufficient amount of $0.1 \mathrm{~N} \mathrm{HCl}$ in a $50 \mathrm{ml}$ volumetric flask and the solution was made up to the mark with $0.1 \mathrm{~N} \mathrm{HCl}$ to prepare the stock solution. Serial dilutions were made from the stock solution to get 20 , $30,40,60,80$ and $100 \mu \mathrm{g} / \mathrm{ml}$ solutions using $0.1 \mathrm{~N} \mathrm{HCl}$ as dilution medium. The absorbance was measured at $271 \mathrm{~nm}$ against $0.1 \mathrm{~N} \mathrm{HCl}$ as blank. All the estimations and dissolution experiments were done in triplicate and average values are reported.

In vitro dissolution studies of BGRFT of ranitidine $\mathrm{HCl}$ and clarithromycin

The tableting properties of weight variation, hardness, friability, assay, in vitro buoyancy studies, in vitro dissolution studies and release rate kinetics of BGRFT were evaluated as described earlier in the previous sections.

Comparison of the dissolution profiles of prepared BGRFT with the commercially available individual tablets of clarithromycin and ranitidine $\mathrm{HCl}$

The main objective of comparing the profiles is to understand the effectiveness of the prepared BGRFT in comparison with the individual marketed tablets of ranitidine $\mathrm{HCl}$ (Histac ${ }^{\circledR 150}$ ) and clarithromycin (Biomycin 250).

\section{Release kinetics}

The analysis of drug release is an important mechanism but, complicated process and is practically evident in the case of matrix systems as a model dependent approach. The dissolution data was fitted into zero [17], and first order for establishing drug release kinetics [18, 19], and Higuchi diffusion model [20], Hixson-Crowell erosion model for establishing drug release mechanism [21].

Zero order model describes the systems where the release rate is independent of the concentration of drug, the first order model describes that the release rate from products is dependent on the concentration of the dissolving drug. Higuchi model describes 
diffusion mechanism of drug release whereas; Hixson-Crowell model describes erosion mechanism of drug release from the products. Korsmeyer-Peppas model further supports the diffusion model of drug release mechanism for further understanding [22, 23]. The respective equations for these models are shown in table 7 . In this regard, the use of in vitro drug dissolution data to predict in vivo bioperformance can be considered as the rational development of immediate release formulations.

Table 7: Mathematical models for comparison of dissolution profiles

\begin{tabular}{lll}
\hline Model & Equation \\
\hline Zero-order & $:$ & $\mathrm{Q}_{\mathrm{t}}=\mathrm{Q}_{0}+\mathrm{k}_{\mathrm{o}} \mathrm{t}$ \\
First-order & $:$ & $\operatorname{InQ}_{\mathrm{t}}=\operatorname{In} \mathrm{Q}_{0}-\mathrm{k}_{1} \mathrm{t}$ \\
Higuchi & $:$ & $\mathrm{Q}_{\mathrm{t}}=\mathrm{k}_{\mathrm{H}} \sqrt{\mathrm{t}}$ \\
Hixson-Crowell & $:$ & $\left(\mathrm{Q}_{0}{ }^{1 / 3}-\mathrm{Q}_{\mathrm{t}}{ }^{1 / 3}\right)=\mathrm{k}_{\mathrm{s}} \mathrm{t}$ \\
Korsmeyer-Peppas & $: \mathrm{Q}_{\mathrm{t}} / \mathrm{Q}_{\alpha}=\mathrm{k}_{\mathrm{k}} \mathrm{t}^{\mathrm{n}}$ \\
\hline
\end{tabular}

Where: $Q_{t}$ : amount of drug released in time $t ; Q_{0}$ : initial amount of drug in the tablet; $Q_{t} / Q_{\infty}$ : fraction of drug released at time $t$; $k_{0}$, $k_{1}, k_{H}, k_{k}, k_{s}$ : release rate constants; $n$ : the release exponent

According to Korsmeyer-Peppas equation, the release exponent ' $n$ ' value is used to characterize different release mechanisms. For a dosage form in cylindrical shape, if the $\mathrm{n}$ value is 0.45 or less, the release mechanism follows Fickian diffusion. If ' $n$ ' value is $0.45<n>0.89$, the mechanism follows non-Fickian (anomalous) diffusion and when ' $n$ ' value is 0.89 it will be non-Fickian case II transport and if $n>0.89$ it will be non-Fickian super case II transport [24].

\section{Drug interaction studies}

\section{Fourier transformation-infrared spectroscopy}

Fourier transformation-infrared spectroscopy (FTIR) is used to identify the drug excipient interaction. FTIR studies were performed on drugs, polymers and optimized formulations. Samples were analyzed by potassium bromide pellet method in an IR spectrophotometer (Shimadzu, FTIR 8700) in the region between $3500-500 \mathrm{~cm}^{-1}$.

\section{In vivo buoyancy studies}

To confirm the spatial and temporal placement of FDDS, a variety of techniques have been used like string technique, endoscopy and gamma scintigraphy [25-29]. Out of these techniques, X-ray technique was used to determine the gastric residence time of the tablets. In the present investigation X-ray studies were conducted for the evaluation of intragastric floating behaviour of the optimized BGRFT of ranitidine $\mathrm{HCl}$ and clarithromycin both in fasted and fed states. The in vivo X-ray evaluation of floating ability studies were carried out by administering BGRFT of ranitidine $\mathrm{HCl}$ and clarithromycin containing barium sulphate $\left(\mathrm{BaSO}_{4}\right)$ in humans in fasted and fed state. Two healthy male subjects of mean age $25 \pm 2$ y (ranging from 23 to 28), mean weight $68 \pm 10 \mathrm{Kg}$ (ranging from 58 to $78 \mathrm{~kg}$ ) and a mean height of $170 \pm 5 \mathrm{~cm}$ (ranging from 165 to $175 \mathrm{~cm}$ ) participated in this study. Based on the previous medical history, physical examination and routine laboratory tests the volunteers were judged healthy. The study was conducted under the guidance of radiologist and both subjects were presented with full details of the investigation, verbally and in written form, prior to providing written informed consent. The study was approved from an independent Institutional Ethics Committee of Andhra University, Visakhapatnam (India). The optimized BGRFT of ranitidine $\mathrm{HCl}$ and clarithromycin was administered to the two volunteers, one under fasted and another one under fed states.

> Fasted state: The subject was fasted overnight and swallowed the BGRFT tablet with $200 \mathrm{ml}$ of water. No food was allowed up to 3 $\mathrm{h}$ of dosing. Subject was not allowed to lay down for sleeping. Every one hour a glass of water $(200 \mathrm{ml})$ was given.

$>$ Fed state: The subject was fasted overnight and in the morning given a high calorie-high fat breakfast with a total calorie value of approximately $900 \mathrm{Cal}$. The BGRFT tablet was administered with $200 \mathrm{ml}$ of water after half an hour of the breakfast. The subject was not allowed to eat anything up to $6 \mathrm{~h}$ but given a glass of water $(200 \mathrm{ml})$ every hour.

\section{Preparation of BGRFT for in vivo studies}

Optimized BGRFT of ranitidine $\mathrm{HCl}$ and clarithromycin containing barium sulphate (BGRFT soB) for in vivo X-ray evaluation were prepared by direct compression method. The amount of ranitidine $\mathrm{HCl}$ and clarithromycin was reduced to 75 and $125 \mathrm{mg}$ for incorporating the barium sulphate (75 and $125 \mathrm{mg}$ ) as radio opaque substance to maintain the constant weight of the tablet. Ranitidine $\mathrm{HCl}$ and clarithromycin (75 and $125 \mathrm{mg}$ ) was geometrically mixed with their respective formulations until a homogeneous blend was achieved. Barium sulphate (75 and $125 \mathrm{mg}$ ) and sodium bicarbonate were added to the above blend, mixed and lubricated with magnesium stearate $(1 \% \mathrm{w} / \mathrm{w})$. The final blend was directly compressed into tablets on a 12-Station rotary punching machine (M/s. Karnavati Engineering Ltd. India) using $12 \mathrm{~mm}$ round flat punches at hardness of $4-6 \mathrm{~kg} / \mathrm{cm}^{2}$.

\section{RESULTS AND DISCUSSION}

In vitro dissolution studies of ranitidine $\mathrm{HCl}$ immediate release tablets

The in vitro dissolution studies of the prepared ranitidine $\mathrm{HCl}$ tablets with different diluents (FR1-FR8) like MCC 101, MCC 102, Ac-di-sol, spray dried lactose, lactose, SSG primogel, DCP, Lycatab and super disintegrants (FR9-FR17) like sodium starch glycolate (SSG), cross carmellose sodium (CCS) and crospovidone (CP) was carried in $0.1 \mathrm{~N} \mathrm{HCl}$ (pH 1.2), for a period of $75 \mathrm{~min}$ and results are shown in fig. 1 and 2.

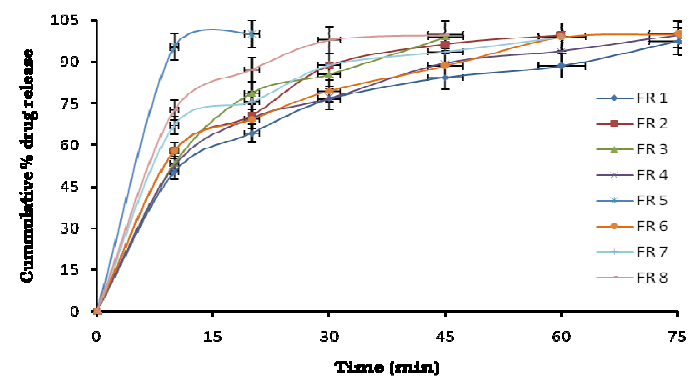

Fig. 1: Dissolution profile of ranitidine $\mathrm{HCl}$ immediate release tablets with different diluents with formulation (FR1 to FR8), (Results are expressed as mean, $n=3$ )

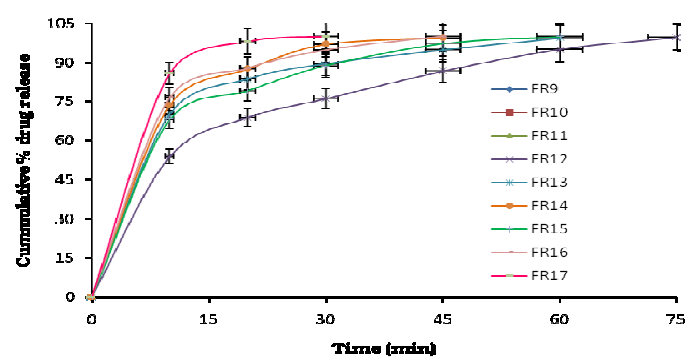

Fig. 2: Dissolution profile of ranitidine $\mathrm{HCl}$ immediate release tablets with different super disintegrants with formulation (FR9 to FR17), (Results are expressed as mean, $n=3$ ) 
All the formulation disintegrated within $10 \mathrm{~min}$. The drug release at $10 \mathrm{~min}$ from FR1 to FR8 tablets was 50.26, 57.75, 53.25, 52.18, $81.26,57.81,66.99$ and $72.47 \%$ respectively. It was observed that while with lactose the release was more than $80 \%$ of drug within 10 min, the other tablets prepared with remaining diluents released $>50 \%$ and $<73 \%$ within $10 \mathrm{~min}$. From the drug release studies and disintegration time, lactose has been selected as optimised diluent for the preparation of immediate release tablets.

From the selected diluent formulation, the super disintegrant and its ratio optimised. The different super disintegrants used in the present study are SSG, CCS and CP. For each disintegrant three ratios ( $2 \%, 3 \%$ and $4 \%$ to the total weight of the tablet) were taken. Super disintegrant based formulations FR9-FR11 containing SSG released more than $95 \%$ in 60,10 and 10 min respectively. CCS based formulations FR12-FR14 released more than $95 \%$ in 75 min, 60 and 45 min respectively. Formulations FR15-FR17 containing CP released more than 95\% in 60, 45 and 30 min respectively. Drug release property was found to be directly proportional to the concentration of super disintegrant.

From the obtained results, it was found that as the concentration of super disintegrant increases, the disintegration time of the tablet decreases and thereby drug release increases [30]. Therefore SSG containing 3\%, CCS containing $4 \%$ and CP containing $4 \%$ were selected as optimised formulations for the IR tablet of ranitidine $\mathrm{HCl}$. Thus, with less concentration of SSG,

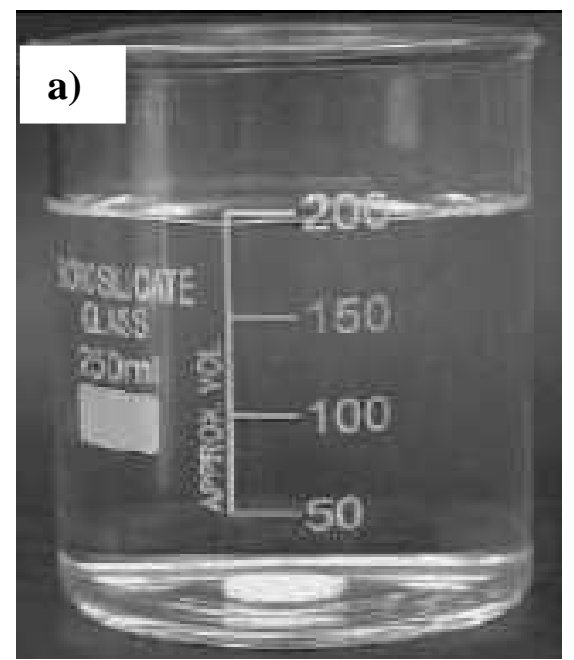

maximum drug release was observed within $10 \mathrm{~min}$.

Therefore from all the formulations, FR10 was optimised and $99.99 \%$ of drug was released in $20 \mathrm{~min}$. When compared with the other super disintegrants, SSG (3\%) showed better release.

The optimised formulation FR10 was compared with the commercial marketed tablets of ranitidine $\mathrm{HCl}$. As the target for complete release of drug is $10 \mathrm{~min}$ in the present investigation, comparative study with commercial formulation was conducted. From the drug release data, it was observed that optimised dissolution profile showed better releases when compared to the commercial marketed product Histac ${ }^{\circledR} 150$ mg tablet.

From the results, it was concluded that the drug release was mainly depended up on concentration of polymer, the drug release varies as the concentration increases the drug release increases (i.e. gives maximum amount of drug release in $10 \mathrm{~min}$ ).

\section{In vitro buoyancy studies}

Initially the concentration of the sodium bicarbonate was optimized for the preparation of the effervescent GFDDS [31]. All the floating tablets were passed physicochemical tests like weight variation, assay and friability. Floating lag times of all the formulations were within the range of 15 to $150 \mathrm{sec}$, the results are given in table 8. As the concentration of sodium bicarbonate increases, the floating lag time found to be decreased as shown in fig. 3 .

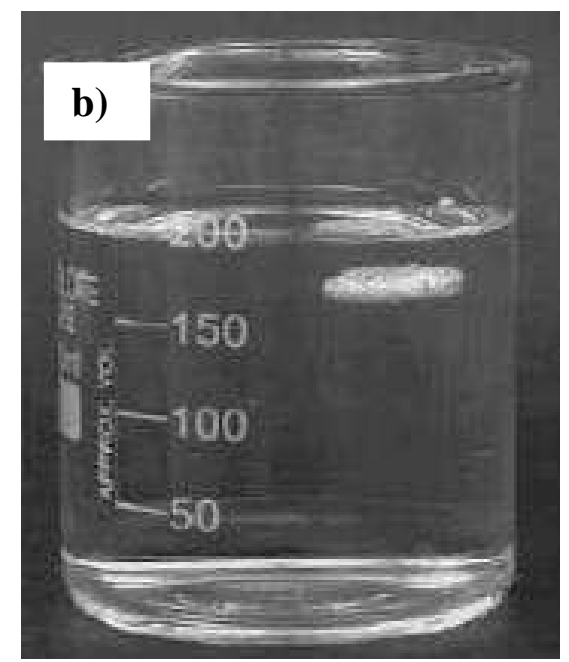

Fig. 3: Floating behaviour of optimised neem gum based formulation (NG07) immediately after placing in the beaker and b) after 30 sec

From the results, it was observed that as the concentration of polymer increased along with concentration of sodium bicarbonate the drug release was retarded. This may be due to increased intensity of air pockets surrounding the jellified surface of the tablet. Increase in the concentration of the sodium bicarbonate at constant polymer concentration also retarded the drug release due to high intensity of the carbon dioxide gas pockets.

Drug retardation was directly proportional to the concentration of polymer, which may be due to the formation of strong compactness between the particles [32].

\section{In vitro dissolution studies of clarithromycin both controlled and gastric floating tablets}

The results of the drug release studies of all the prepared formulations are shown in fig. 4 and 5. Since, there are very few reports on the applicability of the selected natural gums as controlled release polymers, natural gum matrix tablets were prepared to evaluate their efficacy in controlling the drug release of clarithromycin [33-37]. Release retarding effect of concentration of gums on drug release was performed on batches containing neem (NG01-05), damar (DM01-05) and copal (CP01-05). From the dissolution studies, it was concluded that as the concentration of gum increased the drug release was retarded.

Clarithromycin controlled release tablets of neem gum based formulation NG01-05 containing drug-polymer ratios 1:0.4, 1:0.5, 1:0.6, 1:0.7 and 1:0.8 released more than $95 \%$ of drug in $5,6,10,12$ and $14 \mathrm{~h}$ respectively. From the above, it can be concluded that the concentration of neem gum is directly proportional to retarding property of the formulation.

Similarly, the controlled release tablets of clarithromycin prepared with hydrophobic gums of damar gum (DM01-05) and copal gum (CP01-05) in different ratios 1:0.4, 1:0.5, 1:0.6, 1:0.7 and 1:0.8 retards the drug release for 3-8 $\mathrm{h}$ depending on the drug-polymer ratio. As the natural gums have shown retarding capability, they were used in the formulation of effervescent GFT. The effervescent GFT were prepared with hydrophobic gums of gum damar and gum copal, in 1:0.8, 1:0.9 and 1:1 ratios to evaluate their applicability in designing GFT.

As the controlled release tablets of hydrophobic gums failed to retard the drug release up to $12 \mathrm{~h}$ even at 1:0.8 drug-polymers ratio, the GFT were prepared in the above mentioned increasing ratios by using povidone $\mathrm{K} 30$ as binder at $5 \%$ concentration to the total weight to improve binding and to retard the drug release. 
Table 8: Natural um based formulations with the quantities of gum and tableting characteristics (thickness, floating lag time and total floating time)

\begin{tabular}{|c|c|c|c|c|c|c|}
\hline $\begin{array}{l}\text { Formulation } \\
\text { code }\end{array}$ & $\begin{array}{l}\text { Gum quantity } \\
\text { (mg) }\end{array}$ & $\begin{array}{l}\text { Sodium bicarbonate } \\
(\% \mathrm{w} / \mathrm{w})\end{array}$ & $\begin{array}{l}\text { Povidone } \\
(\% w / w)\end{array}$ & $\begin{array}{l}\text { Thickness } \\
\text { (mm) }\end{array}$ & $\begin{array}{l}\text { Floating lag time } \\
\text { (sec) }\end{array}$ & $\begin{array}{l}\text { Total floating } \\
\text { time (hrs) }\end{array}$ \\
\hline NG01 & 100 & - & - & $3.45 \pm 0.11$ & - & - \\
\hline NG02 & 125 & - & - & $3.42 \pm 0.12$ & - & - \\
\hline NG03 & 150 & - & - & $3.26 \pm 0.11$ & - & - \\
\hline NG04 & 175 & - & - & $3.43 \pm 0.14$ & - & - \\
\hline NG05 & 200 & - & - & $3.44 \pm 0.11$ & - & - \\
\hline NG06 & 150 & 62.4 & - & $3.41 \pm 0.13$ & 60 & 10 \\
\hline NG07 & 175 & 62.4 & - & $3.38 \pm 0.12$ & 30 & 12 \\
\hline NG08 & 200 & 62.4 & - & $3.39 \pm 0.11$ & 15 & 14 \\
\hline DM01 & 100 & - & 31 & $3.36 \pm 0.13$ & - & - \\
\hline DM02 & 125 & - & 31 & $3.27 \pm 0.12$ & - & - \\
\hline DM03 & 150 & - & 31 & $3.51 \pm 0.11$ & - & - \\
\hline DM04 & 175 & - & 31 & $3.28 \pm 0.14$ & - & - \\
\hline DM05 & 200 & - & 31 & $3.42 \pm 0.12$ & - & - \\
\hline DM06 & 200 & 74.4 & 31 & $3.55 \pm 0.15$ & 126 & 10 \\
\hline DM07 & 225 & 74.4 & 31 & $3.60 \pm 0.12$ & 90 & 12 \\
\hline DM08 & 250 & 74.4 & 31 & $3.48 \pm 0.13$ & 66 & 14 \\
\hline СР01 & 100 & - & 31 & $3.38 \pm 0.13$ & - & - \\
\hline СР02 & 125 & - & 31 & $3.41 \pm 0.11$ & - & - \\
\hline СР03 & 150 & - & 31 & $3.29 \pm 0.15$ & - & - \\
\hline СР04 & 175 & - & 31 & $3.45 \pm 0.09$ & - & - \\
\hline CP05 & 200 & - & 31 & $3.37 \pm 0.12$ & - & - \\
\hline СР06 & 200 & 74.4 & 31 & $3.52 \pm 0.14$ & 150 & 10 \\
\hline CP07 & 225 & 74.4 & 31 & $3.51 \pm 0.12$ & 78 & 12 \\
\hline СР08 & 250 & 74.4 & 31 & $3.56 \pm 0.11$ & 60 & 14 \\
\hline
\end{tabular}

Each value represents mean $\pm S D(n=5)$ Where n-number of experiments

The effervescent formulations of gum damar (DM06-08) and gum copal (CP06-08) GFT also released more than $98 \%$ of the drug in 10 , 12 and $14 \mathrm{~h}$ respectively. This similarity in drug release may be associated to the fact that both damar and copal gum are gums of hydrophobic nature.

The effervescent GFT prepared with hydrophilic gum i.e. neem gum in 1:0.6, 1:0.7 and 1:0.8 ratios to evaluate the applicability in designing GFT. The formulations of neem gum (NG06-08) retarded the drug release upto 10,12 and $14 \mathrm{~h}$ respectively by increasing the concentration of the polymer.

When compared with the hydrophobic gums, less concentration of polymer is required with hydrophilic gum to achieve the required time period. Hence, neem gum was selected as the suitable polymer for retarding the drug release of clarithromycin controlled release layer with the optimised formulation NG07 released $99.68 \%$ of drug at $12 \mathrm{~h}$.

\section{In vitro dissolution studies of BGRFT}

The drug release profile of the prepared BGRFT was studied and the results are given in and fig. 6 . This BGRFT formulation was prepared to study the effect of immediate release layer (ranitidine $\mathrm{HCl}$ ) on the absorption rate of the controlled release layer (clarithromycin) and their effect on the H. pylori infection [38, 39]. From the dissolution studies it was concluded that the immediate release layer released more than $95 \%$ of ranitidine $\mathrm{HCl}$ within $10 \mathrm{~min}$ and complete release was observed within $30 \mathrm{~min}$.

The controlled release layer of clarithromycin released only $10 \%$ of clarithromycin up to $1 \mathrm{hr}$ from controlled release layer and the tablet started floating within $2 \mathrm{~min}$ and floating continued upto $12 \mathrm{~h}$. The individual layers of the BGRFT have shown similar results as the optimised FR10 (ranitidine $\mathrm{HCl}$ ) and NG07 (clarithromycin) optimised earlier. As the clarithromycin drug release was enhances with the effect of ranitidine $\mathrm{HCl}$.

As there are no marketed product of bilayer tablets of ranitidine $\mathrm{HCl}$ and clarithromycin, the prepared BGRFT formulation of ranitidine $\mathrm{HCl}$ and clarithromycin was compared with the individual marketed products of ranitidine $\mathrm{HCl}$ (Histac ${ }^{\circledR}$ 150) and clarithromycin (Biomycin 250). Ranitidine $\mathrm{HCl}$ marketed product Histac ${ }^{\circledR} 150$ released less than $70 \%$ within $10 \mathrm{~min}$. and clarithromycin marketed product has released more than $30 \%$ within $1 \mathrm{~h}$.
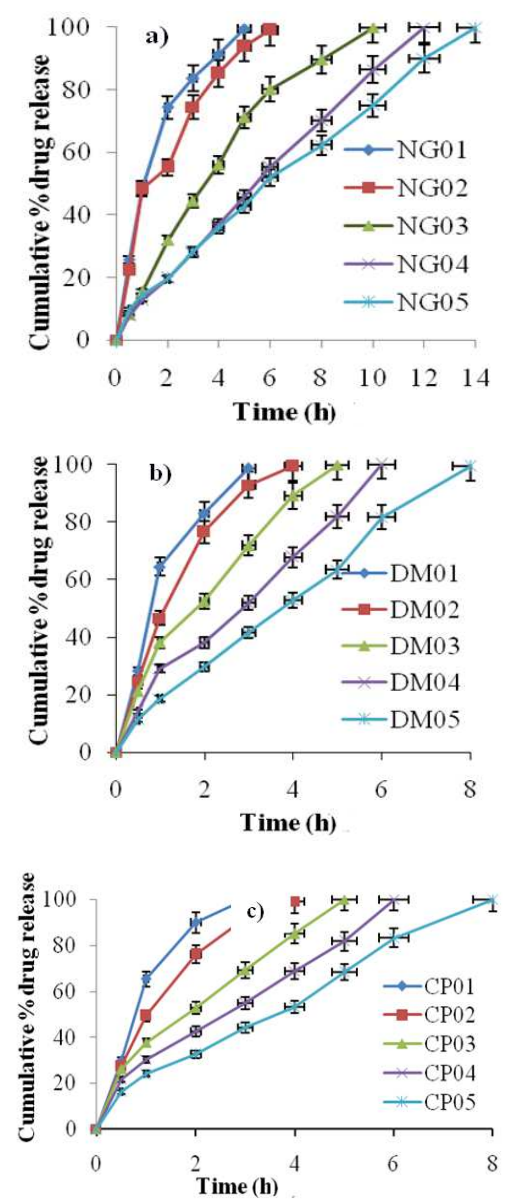

Fig. 4: Dissolution profiles of controlled release tablets of clarithromycin with a) neem gum based formulations (NG01 to NG05), b) damar gum based formulations (DM01 to DM05) and c) copal gum based formulations (CP01 to CP05). (Results are expressed as mean, $n=3$ ) 

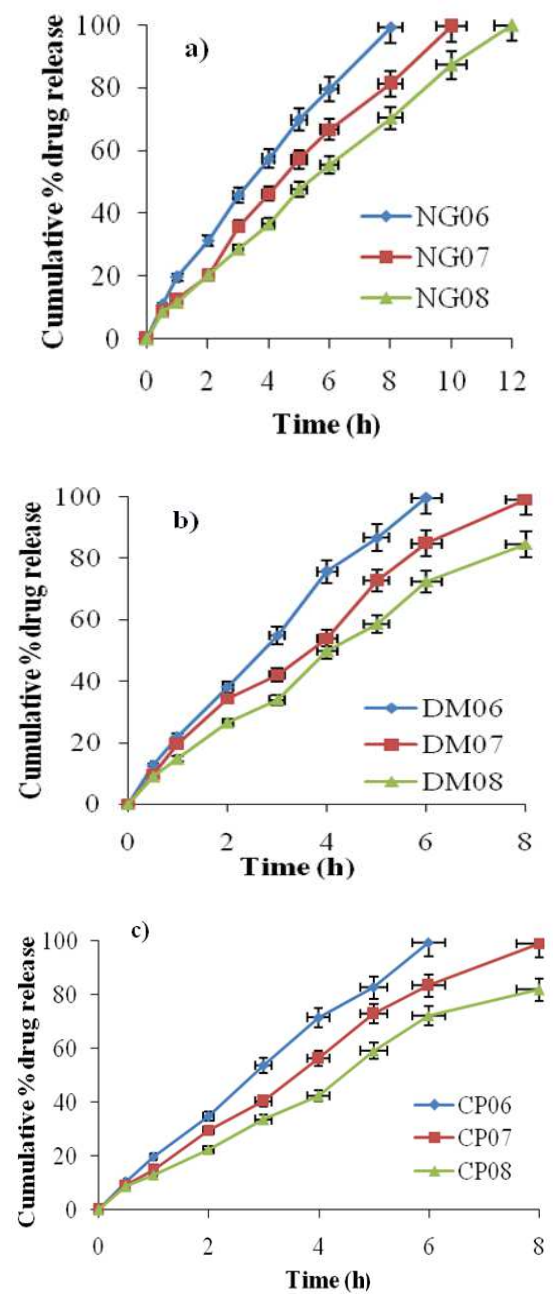

Fig. 5: Dissolution profiles of effervescent gastroretentive floating tablets of clarithromycin using sodium bicarbonate with a) neem gum based formulations (NG06 to NG08), b) damar gum based formulations (DM06 to DM08)and c) copal gum based formulations (CP06 to CP08). (Results are expressed as mean, $n=3$ )

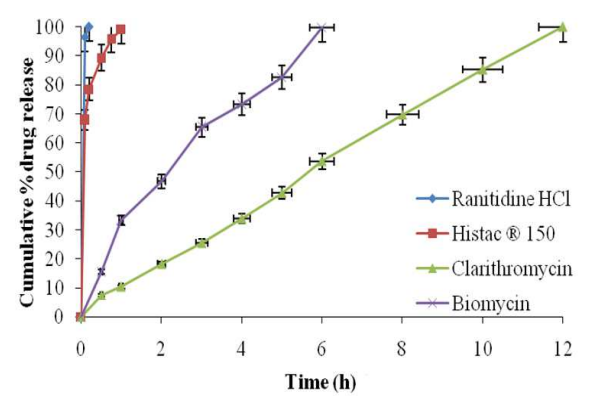

Fig. 6: Dissolution profiles of bilayer retentive gastric floating tablet containing ranitidine $\mathrm{HCl}$ and clarithromycin and conventional marketed tablets Histac ${ }^{\circledR} 150$ and Biomycin. (Results are expressed as mean, $n=3$ )

\section{Release kinetics}

The dissolution data was fitted to kinetic parameters and the correlation coefficient values (' $r$ ') of release kinetics of all the ranitidine $\mathrm{HCl}$ formulations are given in table 9. The appropriate correlation coefficient values are highlighted with bold letters indicating the order and release mechanism followed by the respective formulations. The formulations prepared with different diluents FR1 to FR17 followed first order and Fickian diffusion mechanism. The dissolution data of batches FR1 to FR17 was fitted to zero-order, first-order, Higuchi, Hixson-Crowell and KorsmeyerPeppas models. The drug release data from the ranitidine $\mathrm{HCl}$ tablets was best explained by the first order release kinetics. Formulations FR1, FR3 and FR11 followed diffusion mechanism with regression correlation coefficient values $0.9550,0.9821$ and 0.9303 . The remaining formulations followed erosion mechanism.

The release kinetics of all the formulations of clarithromycin was given in table 10 and 11. Neem gum based formulations NG01 and NG02 followed first order release rate kinetics with regression values 0.8828 and 0.9115 with non-Fickian mechanism due to low concentration of polymer and rapid disintegration of tablets. Formulations NG03, NG04 and NG05 followed zero order kinetics with non-Fickian diffusion mechanism.

Formulations prepared with damar gum DM01 and DM02 followed first order release rate kinetics with regression values 0.9331 and 0.9324 with erosion mechanism. The formulations DM03, DM04 and DM05 followed zero order kinetics with non-Fickian diffusion mechanism. Copal gum based formulations CP01 and CP02 followed first order release rate kinetics with regression values 0.8930 and 0.9429 with erosion mechanism. Formulations CP03, CP04 and CP05 followed zero order kinetics with non-Fickian diffusion mechanism. Moreover, due to the hydrophobic nature of the damar and copal gums they followed biphasic mechanism for higher concentration formulations.

The effervescent natural gum formulations NG06-08, DM06-08 and CP06-08 followed zero order kinetics with a non-Fickian diffusion mechanism. Drug release from the optimized effervescent GFT NG07 followed zero order kinetics with nonFickian diffusion mechanism. There was no significant change in release mechanism by altering the concentration of polymers after attaining the achieved time period.

\section{Where BGRFT-bilayer gastric retentive floating tablets}

BGRFT release kinetics in comparision with individual marketed products was given in table 12 . The immediate release layer and Histac $^{\circledR} 150$ followed first order release kinetics and controlled released layer and Biomycin 250 followed zero order kinetics with Fickian diffusion mechanism.

\section{Drug interaction studies}

\section{Fourier transformation-infrared spectroscopy}

There is always a possibility of drug-excipient interaction in the formulation due to their intimate contact. FTIR studies were used to study the drug-excipient interaction of the optimized formulations and their respective powders. The FTIR spectra of the optimised formulations were compared with the respective spectra of pure drugs and respective polymers. Characteristic spectra of the drugs clarithromycin and ranitidine $\mathrm{HCl}$ in the optimized formulation along with each individual excipient layers are shown in fig. 7 to 9.

The FTIR spectrum of pure ranitidine $\mathrm{HCl}$ [40-42], showed characteristic $0-\mathrm{H}$ dimer stretch at $3256 \mathrm{~cm}^{-1}$ and $3191 \mathrm{~cm}^{-1}, \mathrm{C}-\mathrm{H}$ stretch at $3097 \mathrm{~cm}^{-1}$ and $2974 \mathrm{~cm}^{-1}, \mathrm{~N}-\mathrm{H}$ bond in protonated tertiary amine group at $2465 \mathrm{~cm}^{-1}$, a strong primary amine at $1620 \mathrm{~cm}^{-1}$ which corresponds to the $\mathrm{C}=\mathrm{N}$ stretch in an aci-nitro group of nitronic acid, nitro group attached to a saturated carbon atom with a stretch alkanes at $1418 \mathrm{~cm}^{-1}$ and amines at $1252 \mathrm{~cm}^{-1}, \mathrm{C}-0$ stretch at $1006 \mathrm{~cm}^{-1}, \mathrm{C}-\mathrm{Cl}$ stretch at $761 \mathrm{~cm}^{-1}$ and $\mathrm{C}-\mathrm{H}$ alkenes stretch at 701 $\mathrm{cm}^{-1}$.

The FTIR spectra of sodium starch glycolate showed the characteristic $\mathrm{O}-\mathrm{H}$ alcohols stretch at $3693 \mathrm{~cm}^{-1}, \mathrm{O}-\mathrm{H}$ carboxylic acid stretch at $2885 \mathrm{~cm}^{-1}, \mathrm{C}=0$ carboxylic acid stretch at $1745 \mathrm{~cm}^{-1}$, C-O carboxylic acid stretch at $1118 \mathrm{~cm}^{-1}$ and a C-H alkenes stretch at $917 \mathrm{~cm}^{-1}$.

The optimized formulation FR10 showed all the characteristic peaks of ranitidine $\mathrm{HCl}$ with minor shifts in the FTIR spectrum. The spectrum showed $0-\mathrm{H}$ dimer stretch at $3257 \mathrm{~cm}^{-1}$ and 3191 $\mathrm{cm}^{-1}, \mathrm{C}-\mathrm{H}$ stretch at $3097 \mathrm{~cm}^{-1}$ and $2974 \mathrm{~cm}^{-1}, \mathrm{~N}-\mathrm{H}$ bond in 
protonated tertiary amine group at $2466 \mathrm{~cm}^{-1}$, a strong primary amine at $1620 \mathrm{~cm}^{-1}$ which corresponds to the $\mathrm{C}=\mathrm{N}$ stretch in an aci-nitro group of nitronic acid, nitro group attached to a saturated carbon atom with a stretch alkanes at $1418 \mathrm{~cm}^{-1}$ and amines at $1252 \mathrm{~cm}^{-1}, \mathrm{C}-0$ stretch at $1006 \mathrm{~cm}^{-1}, \mathrm{C}-\mathrm{Cl}$ stretch at 762 $\mathrm{cm}^{-1}$ and a C-H alkenes stretch at $701 \mathrm{~cm}^{-1}$.
The FTIR spectrum of pure clarithromycin [43-46], showed characteristic $\mathrm{O}-\mathrm{H}$ stretch at $3469 \mathrm{~cm}^{-1}, \mathrm{C}-\mathrm{H}$ aliphatic stretch at $2978 \mathrm{~cm}^{-1}, \mathrm{C}=0$ ketone stretch at $1726 \mathrm{~cm}^{-1}$ and $1691 \mathrm{~cm}^{-1}, \mathrm{C}-\mathrm{H}$ aromatic stretch at $1459 \mathrm{~cm}^{-1}, \mathrm{C}-\mathrm{O}$ tertiary alcohol stretch at 1173 $\mathrm{cm}^{-1}, \mathrm{C}-\mathrm{N}$ stretch aliphatic amines at $1011 \mathrm{~cm}^{-1}$ and $\mathrm{C}-\mathrm{H}$ cisdisubstituted alkenes stretch at $633 \mathrm{~cm}^{-1}$.

Table 9: Correlation coefficient values and release kinetics of ranitidine $\mathrm{HCl}$ immediate release tablets

\begin{tabular}{|c|c|c|c|c|c|c|c|c|}
\hline \multirow[t]{2}{*}{ Formulation } & \multicolumn{2}{|c|}{ Zero order } & \multicolumn{2}{|c|}{ First order } & \multirow{2}{*}{$\begin{array}{l}\text { Higuchi } \\
\mathbf{r}\end{array}$} & \multirow{2}{*}{$\begin{array}{l}\text { Hixson-Crowell } \\
\text { R }\end{array}$} & \multicolumn{2}{|l|}{ Peppas } \\
\hline & $\mathbf{K}_{\mathbf{0}}$ & $\mathbf{r}$ & $\mathbf{K}_{1}$ & $\mathbf{r}$ & & & n & $\mathbf{r}$ \\
\hline FR1 & 1.0578 & 0.7562 & 0.0182 & 0.9471 & 0.9550 & 0.9439 & 0.3212 & 0.9871 \\
\hline FR2 & 1.4499 & 0.7511 & 0.0403 & 0.9504 & 0.9539 & 0.9812 & 0.3232 & 0.9664 \\
\hline FR3 & 2.0316 & 0.8253 & 0.0411 & 0.9357 & 0.9821 & 0.9820 & 0.4053 & 0.9652 \\
\hline FR4 & 1.0925 & 0.7467 & 0.0266 & 0.9111 & 0.9512 & 0.9655 & 0.3166 & 0.9857 \\
\hline FR5 & 4.9995 & 0.8781 & 0.1000 & 0.9797 & 0.9852 & 0.9978 & 0.2816 & 1.0000 \\
\hline FR6 & 1.0909 & 0.7306 & 0.0365 & 0.9128 & 0.9416 & 0.9728 & 0.2849 & 0.9927 \\
\hline FR7 & 1.3406 & 0.6695 & 0.0297 & 0.9669 & 0.9096 & 0.9293 & 0.2260 & 0.9747 \\
\hline FR8 & 1.9581 & 0.6838 & 0.0559 & 0.9891 & 0.9193 & 0.9438 & 0.2232 & 0.9538 \\
\hline FR9 & 1.3829 & 0.7172 & 0.0320 & 0.9377 & 0.9391 & 0.9559 & 0.2797 & 0.9859 \\
\hline FR10 & 4.9995 & 0.7864 & 0.2000 & 0.9620 & 0.9489 & 0.9648 & 0.0720 & 1.0000 \\
\hline FR11 & 4.9495 & 0.7686 & 0.0998 & 0.9330 & 0.9303 & 0.8526 & 0.0362 & 1.0000 \\
\hline FR12 & 1.0862 & 0.7515 & 0.0264 & 0.9173 & 0.9531 & 0.9693 & 0.3054 & 1.0000 \\
\hline FR13 & 1.3076 & 0.6192 & 0.0312 & 0.9633 & 0.8788 & 0.9052 & 0.1912 & 0.9819 \\
\hline FR14 & 1.9287 & 0.6709 & 0.0454 & 0.9923 & 0.9117 & 0.9194 & 0.2072 & 0.9606 \\
\hline FR15 & 1.3584 & 0.6637 & 0.0388 & 0.9658 & 0.9074 & 0.9541 & 0.2235 & 0.9896 \\
\hline FR16 & 1.8996 & 0.6541 & 0.0556 & 0.9463 & 0.9003 & 0.9419 & 0.1797 & 0.9935 \\
\hline FR17 & 3.1168 & 0.7134 & 0.0913 & 0.9951 & 0.9199 & 0.9405 & 0.1449 & 0.9371 \\
\hline
\end{tabular}

Table 10: Correlation coefficient values and release kinetics of clarithromycin controlled release tablets with natural gums (neem, damarand copal)

\begin{tabular}{|c|c|c|c|c|c|c|c|c|}
\hline \multirow[t]{2}{*}{ Formulation } & \multicolumn{2}{|c|}{ Zero order } & \multicolumn{2}{|c|}{ First order } & \multirow{2}{*}{$\begin{array}{l}\text { Higuchi } \\
\mathbf{r} \\
\end{array}$} & \multicolumn{2}{|c|}{ Hixson-Crowell } & \multirow{2}{*}{$\begin{array}{l}\text { Peppas } \\
\mathbf{r}\end{array}$} \\
\hline & $\mathbf{K}_{\mathbf{0}}$ & $\mathbf{R}$ & $K_{1}$ & $\mathbf{r}$ & & $\mathbf{R}$ & $\mathbf{n}$ & \\
\hline NG01 & 18.493 & 0.8719 & 0.388 & 0.8828 & 0.9795 & 0.9594 & 0.5706 & 0.9546 \\
\hline NG02 & 15.283 & 0.9006 & 0.289 & 0.9115 & 0.9848 & 0.9729 & 0.5623 & 0.9499 \\
\hline NG03 & 10.387 & 0.9519 & 0.224 & 0.7716 & 0.9906 & 0.9617 & 0.8588 & 0.9887 \\
\hline NG04 & 8.272 & 0.9974 & 0.209 & 0.6021 & 0.9681 & 0.8664 & 0.8121 & 0.9927 \\
\hline NG05 & 6.924 & 0.9931 & 0.141 & 0.6686 & 0.9735 & 0.8942 & 0.7164 & 0.9876 \\
\hline DM01 & 31.681 & 0.8935 & 0.596 & 0.9331 & 0.9392 & 0.9855 & 0.6719 & 0.9161 \\
\hline DM02 & 24.657 & 0.9187 & 0.521 & 0.9324 & 0.9753 & 0.9988 & 0.6772 & 0.9736 \\
\hline DM03 & 19.104 & 0.9673 & 0.458 & 0.7399 & 0.9927 & 0.9317 & 0.6586 & 0.9926 \\
\hline DM04 & 15.478 & 0.9876 & 0.343 & 0.6200 & 0.9671 & 0.8408 & 0.7330 & 0.9838 \\
\hline DM05 & 12.218 & 0.9939 & 0.218 & 0.7374 & 0.9676 & 0.8977 & 0.7828 & 0.9945 \\
\hline СР01 & 32.647 & 0.8845 & 0.921 & 0.8930 & 0.9334 & 0.9940 & 0.6676 & 0.9210 \\
\hline СР02 & 24.012 & 0.9114 & 0.471 & 0.9429 & 0.9789 & 0.9986 & 0.6252 & 0.9758 \\
\hline СР03 & 18.279 & 0.9643 & 0.483 & 0.6731 & 0.9878 & 0.8908 & 0.5747 & 0.9937 \\
\hline СР04 & 14.944 & 0.9789 & 0.381 & 0.5875 & 0.9662 & 0.8285 & 0.6009 & 0.9832 \\
\hline СР05 & 11.965 & 0.9860 & 0.267 & 0.6868 & 0.9620 & 0.8845 & 0.6542 & 0.9800 \\
\hline
\end{tabular}

Table 11: Correlation coefficient values and release kinetics of effervescent GFT of clarithromycin natural gums

\begin{tabular}{|c|c|c|c|c|c|c|c|c|}
\hline \multirow[t]{2}{*}{ Formulation } & \multicolumn{2}{|c|}{ Zero order } & \multicolumn{2}{|c|}{ First order } & \multirow{2}{*}{$\begin{array}{l}\text { Higuchi } \\
\mathbf{r}\end{array}$} & \multicolumn{2}{|c|}{ Hixson-Crowell } & \multirow{2}{*}{$\begin{array}{l}\text { Peppas } \\
\mathbf{r}\end{array}$} \\
\hline & $\mathbf{K}_{\mathbf{0}}$ & $\mathbf{r}$ & $\mathbf{K}_{1}$ & $\mathbf{r}$ & & $\mathbf{R}$ & $\mathbf{n}$ & \\
\hline NG06 & 9.909 & 0.9670 & 0.172 & 0.8184 & 0.9889 & 0.9585 & 0.7390 & 0.9950 \\
\hline NG07 & 8.144 & 0.9969 & 0.167 & 0.6538 & 0.9655 & 0.8742 & 0.7802 & 0.9860 \\
\hline NG08 & 6.824 & 0.9944 & 6.442 & 0.7270 & 0.9714 & 0.9036 & 0.7368 & 0.9886 \\
\hline DM06 & 9.453 & 0.9694 & 0.169 & 0.7685 & 0.9949 & 0.9304 & 0.6912 & 0.9967 \\
\hline DM07 & 7.935 & 0.9662 & 0.176 & 0.6453 & 0.9905 & 0.8886 & 0.7192 & 0.9957 \\
\hline DM08 & 6.665 & 0.9867 & 0.136 & 0.6072 & 0.9788 & 0.8537 & 0.7264 & 0.9959 \\
\hline CP06 & 9.541 & 0.9599 & 0.187 & 0.7619 & 0.9915 & 0.9377 & 0.6499 & 0.9957 \\
\hline СР07 & 7.965 & 0.9585 & 0.168 & 0.7312 & 0.9925 & 0.9363 & 0.6625 & 0.9887 \\
\hline СР08 & 6.908 & 0.9775 & 0.103 & 0.8636 & 0.9902 & 0.9680 & 0.7258 & 0.9968 \\
\hline
\end{tabular}

Where GFT-gastroretentive floating tablets

Table 12: Correlation coefficient values and release kinetics of BGRFT and marketed products

\begin{tabular}{|c|c|c|c|c|c|c|c|c|}
\hline \multirow[t]{2}{*}{ Formulation } & \multicolumn{2}{|c|}{ Zero order } & \multicolumn{2}{|c|}{ First order } & \multirow{2}{*}{$\begin{array}{l}\text { Higuchi } \\
\mathbf{r}\end{array}$} & \multicolumn{2}{|c|}{ Hixson-Crowell } & \multirow{2}{*}{$\begin{array}{l}\text { Peppas } \\
\mathbf{r}\end{array}$} \\
\hline & $\mathbf{K}_{\mathbf{0}}$ & $\mathbf{r}$ & $\mathbf{K}_{1}$ & $\mathbf{r}$ & & $\mathbf{r}$ & n & \\
\hline Ranitidine $\mathrm{HCl}$ from BGRFT & 179.64 & 0.6139 & 8.696 & 0.8960 & 0.8146 & 0.8022 & 0.0335 & 0.8702 \\
\hline Clarithromycin from BGRFT & 8.324 & 0.9984 & 0.189 & 0.6207 & 0.9593 & 0.8635 & 0.8519 & 0.9872 \\
\hline Histac $^{\circledR} 150$ & 80.26 & 0.6533 & 1.951 & 0.9834 & 0.9661 & 0.9328 & 0.2159 & 0.9864 \\
\hline Biomycin 250 & 15.42 & 0.9624 & 0.340 & 0.6542 & 0.9897 & 0.8792 & 0.6991 & 0.9817 \\
\hline
\end{tabular}




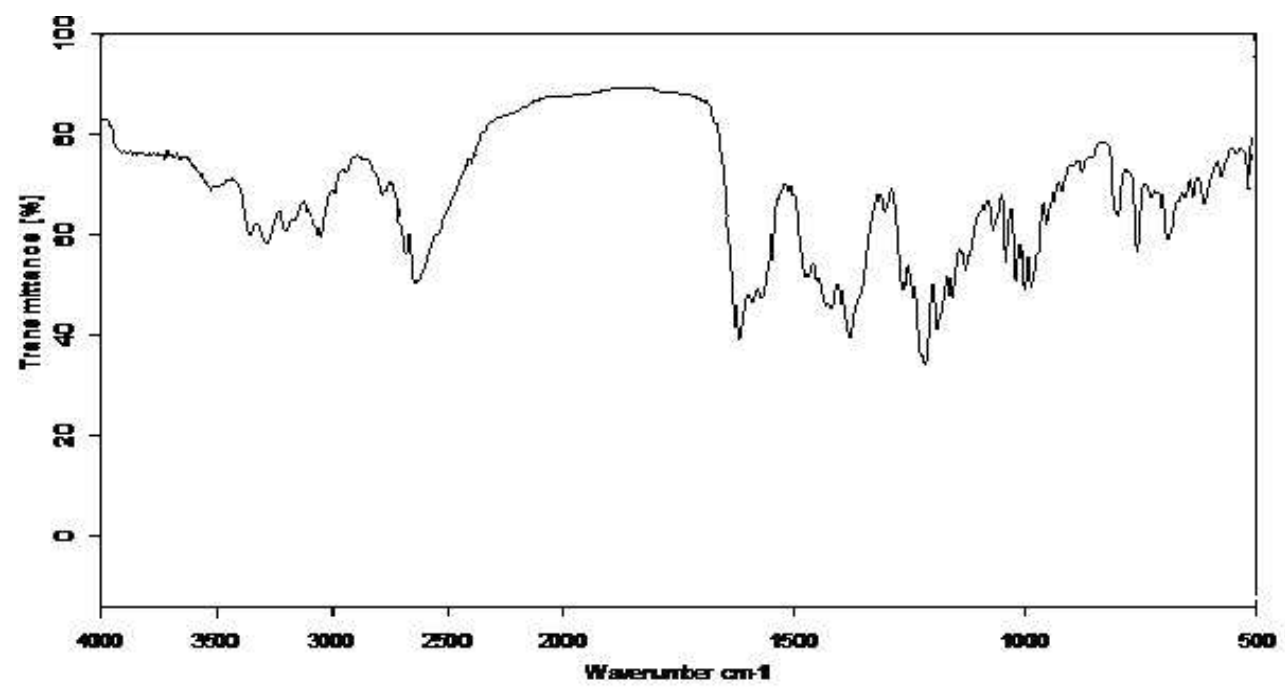

a

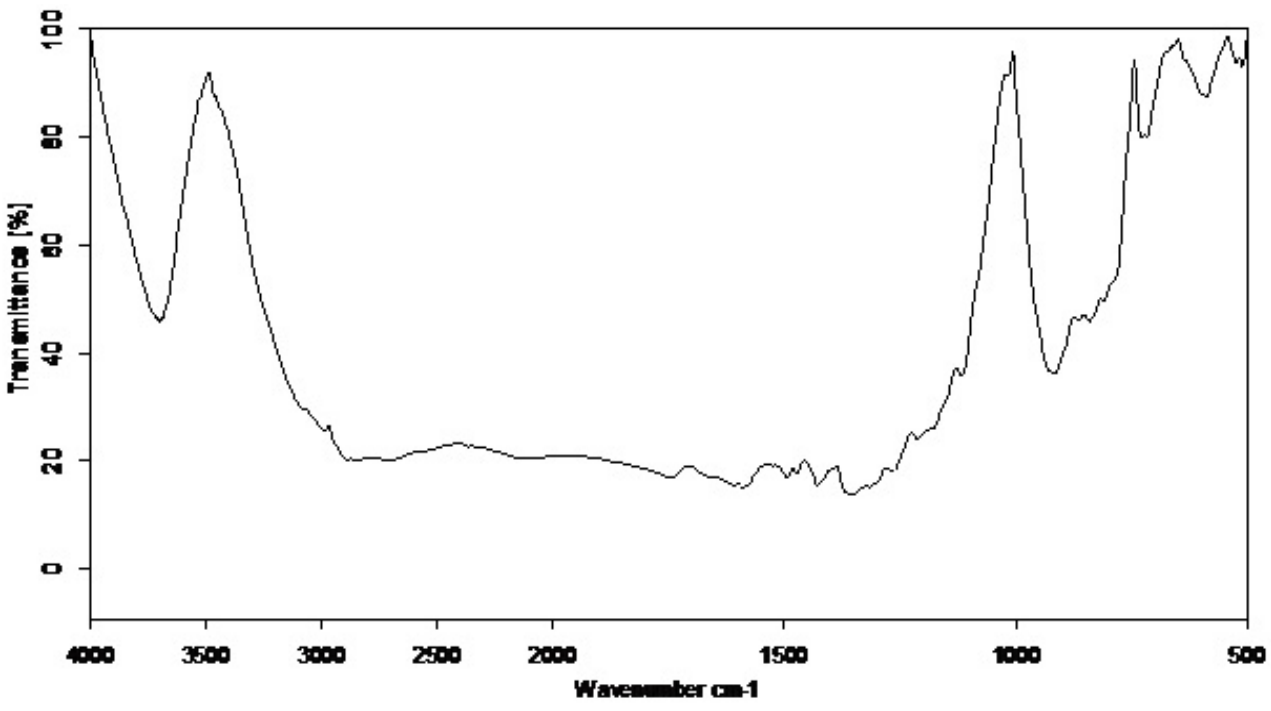

b

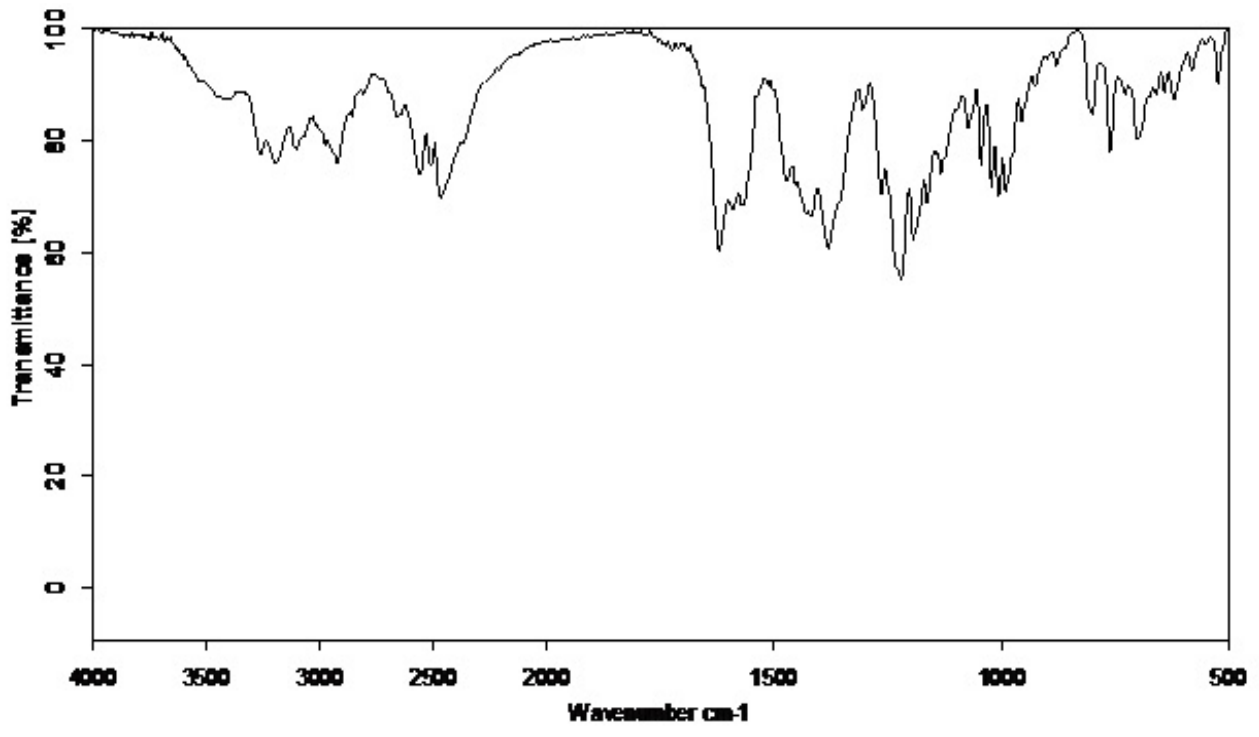

c

Fig. 7: FTIR spectra of (a) Ranitidine $\mathrm{HCl}$ (b) Sodium starch glycolate (c) Ranitidine HCl optimised formulation (FR10) 


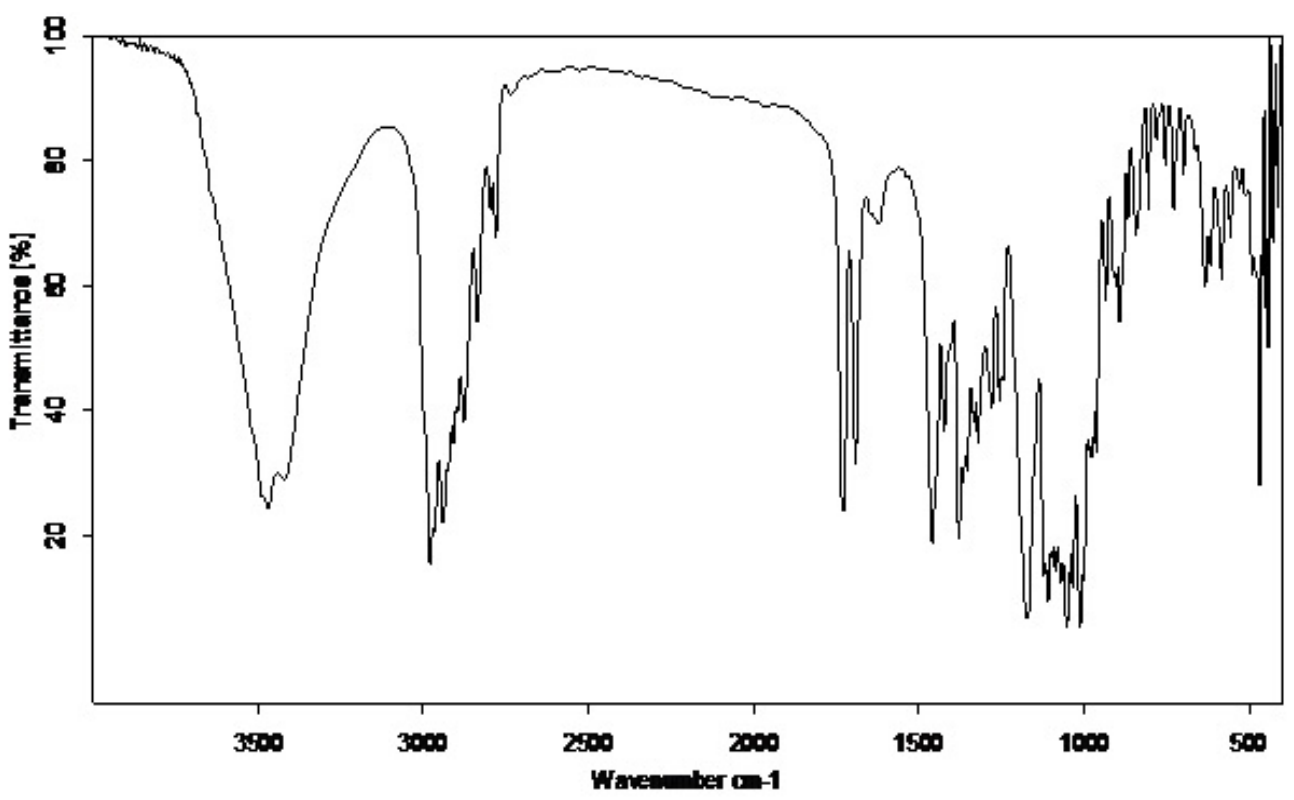

a
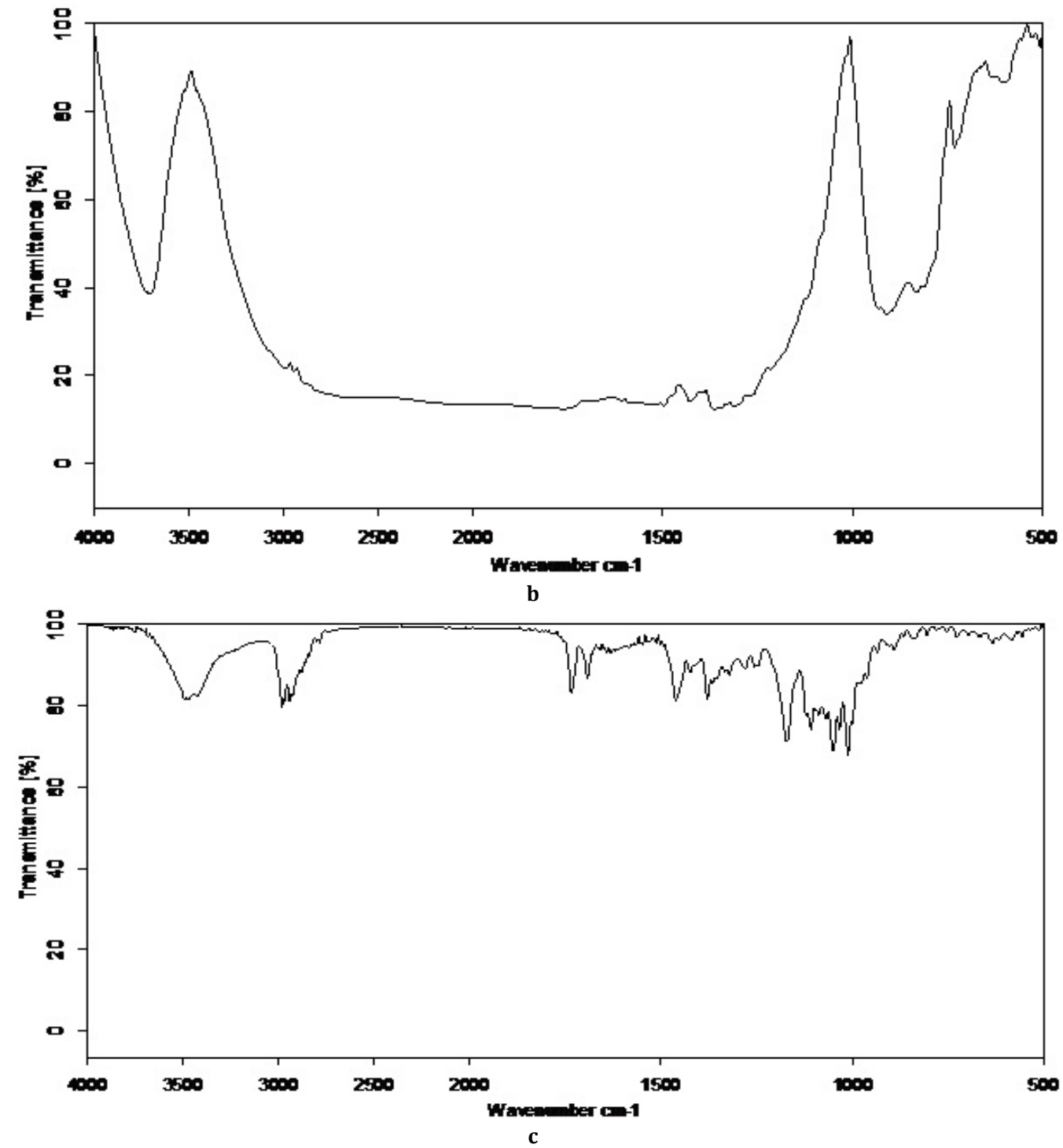

Fig. 8: FTIR spectra of (a) clarithromycin (b) Neem gum (c) clarithromycin optimised formulation (NG07) 


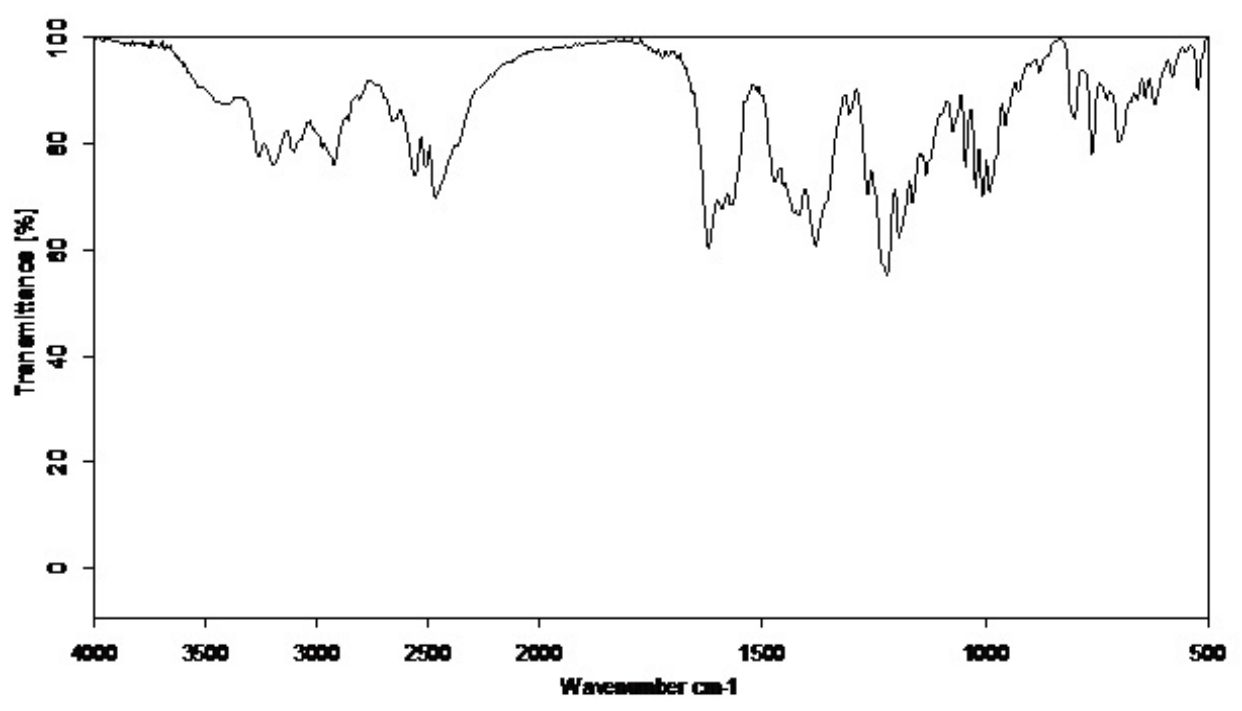

a
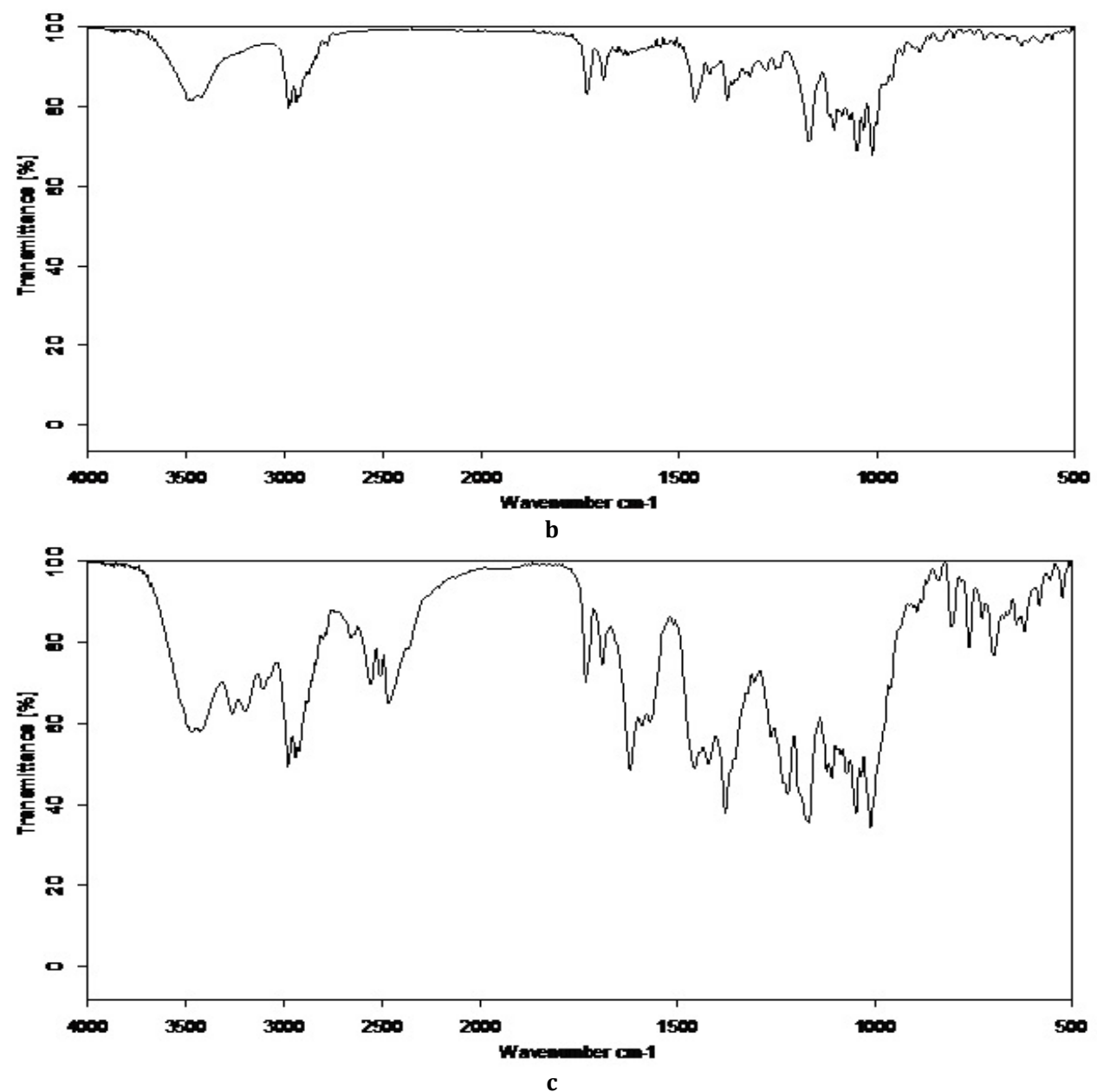

Fig. 9: FTIR spectra of (a) ranitidine HCl optimised formulation (FR10) (b) clarithromycin optimised formulation (NG07) (c) bilayer gastric retentive floating tablets (BGRFT)

The FTIR spectra of neem gum showed the characteristic N-H secondary amines stretch at $3702 \mathrm{~cm}-1$, alcoholic $0-\mathrm{H}$ stretch at $2988 \mathrm{~cm}-1, \mathrm{C}-0$ carboxylic acid anhydride stretch at $1763 \mathrm{~cm}-1, \mathrm{C}=\mathrm{C}$ aromatic stretch at $1494 \mathrm{~cm}-1, \mathrm{C}-\mathrm{H}$ alkanes stretch at $1428 \mathrm{~cm}-1$ and $1365 \mathrm{~cm}-1$ and C-H alkenes stretch at $911 \mathrm{~cm}-1$.

The optimised neem gum based formulation NG07 showed all characteristic peaks of clarithromycin with minor shifts in its FTIR spectrum. The spectrum showed $\mathrm{O}-\mathrm{H}$ stretch at $3468 \mathrm{~cm}-1$, aliphatic stretch C-H at $2978 \mathrm{~cm}-1, \mathrm{C}-0$ carboxylic acid anhydride stretch at $1763 \mathrm{~cm}-1, \mathrm{C}=0$ ketone stretch at $1725 \mathrm{~cm}-1$ and 1692 $\mathrm{cm}-1, \mathrm{C}=\mathrm{C}$ aromatic stretch at $1495 \mathrm{~cm}-1, \mathrm{C}-\mathrm{H}$ aromatic stretch at $1460 \mathrm{~cm}-1, \mathrm{C}-\mathrm{H}$ alkanes stretch at $1365 \mathrm{~cm}-1, \mathrm{C}-0$ tertiary alcohol stretch at $1172 \mathrm{~cm}-1, \mathrm{C}-\mathrm{N}$ stretch aliphatic amines at $1012 \mathrm{~cm}-1, \mathrm{C}$ - 
$\mathrm{H}$ alkenes stretch at $911 \mathrm{~cm}-1$ and $\mathrm{C}-\mathrm{H}$ cis-disubstituted alkenes stretch at $633 \mathrm{~cm}-1$.

The prepared bilayer gastric retentive floating tablets BGRFT showed all the characteristic peaks of clarithromycin and ranitidine $\mathrm{HCl}$ with minor shifts in its FTIR spectrum. The spectrum showedO-H stretch at $3465 \mathrm{~cm}-1$, aliphatic stretch C-H at $2977 \mathrm{~cm}-1, \mathrm{~N}-\mathrm{H}$ bond in protonated tertiary amine group at $2466 \mathrm{~cm}-1, \mathrm{C}=0$ ketone stretch at $1725 \mathrm{~cm}-1$ and $1691 \mathrm{~cm}-1$, a strong primary amine at $1620 \mathrm{~cm}-1$ which corresponds to the $\mathrm{C}=\mathrm{N}$ stretch in an aci-nitro group of nitronic acid, C-H alkanes stretch at $1365 \mathrm{~cm}-1$, nitro group attached to a saturated carbon atom with a stretch alkanes at 1420 $\mathrm{cm}-1$ and amines at $1264 \mathrm{~cm}-1, \mathrm{C}-0$ tertiary alcohol stretch at 1172 $\mathrm{cm}-1$ and $\mathrm{C}-\mathrm{Cl}$ stretch at $761 \mathrm{~cm}-1$.
The FTIR spectra data indicated the absence of any chemical interaction between clarithromycin, ranitidine $\mathrm{HCl}$ and studied polymers sodium starch glycolate and neem gum.

\section{In vivo buoyancy studies}

The main aim of this study was to examine the buoyancy and gastric retention of the floating tablet system under both fasted and fed state conditions of healthy volunteers participated in the study. A radiological method was employed to monitor the gastric region of volunteers in different feeding conditions after administration of the developed GRFT. The GRFT of BGRFT remained buoyant on gastric content under both fasted and fed states in volunteers participated in the present study but variations in gastric retention time and buoyancy were observed in fasting and fed state conditions, given in table 13.

Table 13: In vivo residence time of the optimized BGRFT ofranitdine $\mathrm{HCl}$ and clarithromycin containing barium sulphate (BGRFTsoB)

\begin{tabular}{lll}
\hline Time (h) & Position of the tablet in GIT & Fasted state \\
\cline { 2 - 3 } & Fed state & Stomach \\
\hline 0.5 & Stomach & Stomach \\
2 & Stomach & Small intestine \\
4 & Stomach & Disappeared from gastric region \\
6 & Stomach & - \\
\hline
\end{tabular}

Where BGRFT-bilayer gastri retentive floating tablets, and BGRFTsoB)-optimized bilayer gastric retentive floating tablet of ranitidine HCl and clarithromycin containing barium sulphate.

The buoyancy of developed BGRFT under fasted conditions was observed on the gastric fluid at $2^{\text {nd }} \mathrm{hr}$ as shown in fig. 10 (aandb) and in the small intestine after $4 \mathrm{~h}$ as shown in fig. 10 (c) and was disappeared at $6^{\text {th }} \mathrm{h}$ as shown in fig. 10 (d). As a result of this activity, dosage form administered to fasted subjects could be emptied as rapidly as within an hour or two, depending on the presence of the strong motor induced contractile activity [19].

In the fed state after the high calorie high fat breakfast, the BGRFT was observed to be buoyant on the gastric contents up to $6 \mathrm{~h}$ after administration as shown in fig. 11 (a) at $0.5 \mathrm{~h}$, fig. 11 (b) at $2 \mathrm{~h}$, fig. 11 (c) at $4 \mathrm{~h}$, fig. 11 (d) at $6 \mathrm{~h}$ and disappeared at $8 \mathrm{~h}$ shown in fig. 11 (e). Hence, in the fed condition, the floating system showed a 5 to $6 \mathrm{~h}$ of prolonged GRT over the fasted state. The evaluation of the BGRFT of ranitidine $\mathrm{HCl}$ and clarithromycin intragastric behaviour in humans, showed the actual floatability of the tablet on the gastric content. This study has demonstrated that in the fasted state under the influence of strong motor activity, there was no enhancement of GRT of gastro retentive floating tablet, whereas there was a prolonged GRT of approximately $6 \mathrm{~h}$ in a fed state.
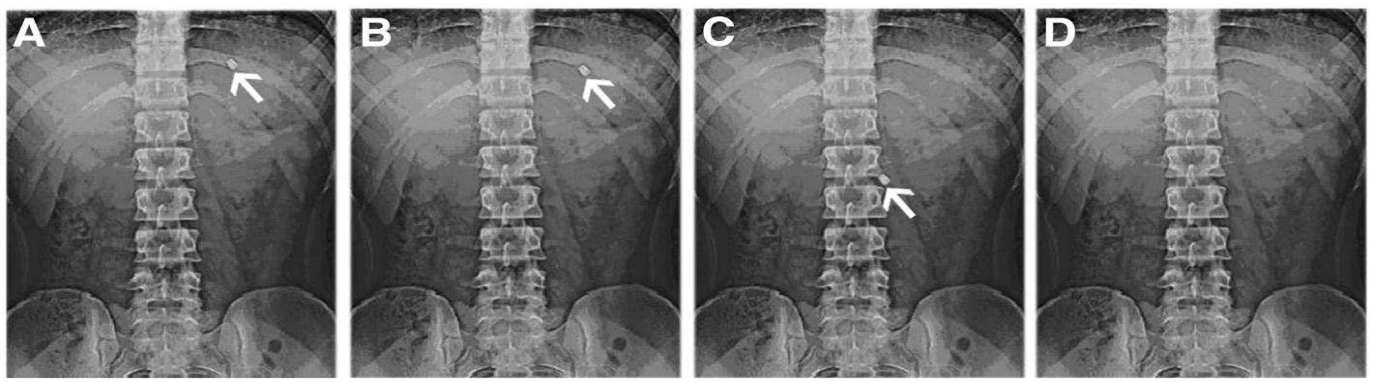

Fig. 10: X-ray photographs of gastric floating tablets of bilayer gastric retentive floating tablets containing ranitidine $\mathrm{HCl}$ and clarithromycin under fasted state after (a) $0.5 \mathrm{~h} \mathrm{(b)} 2 \mathrm{~h}$ (c) $4 \mathrm{~h}$ and (d) $6 \mathrm{~h}$
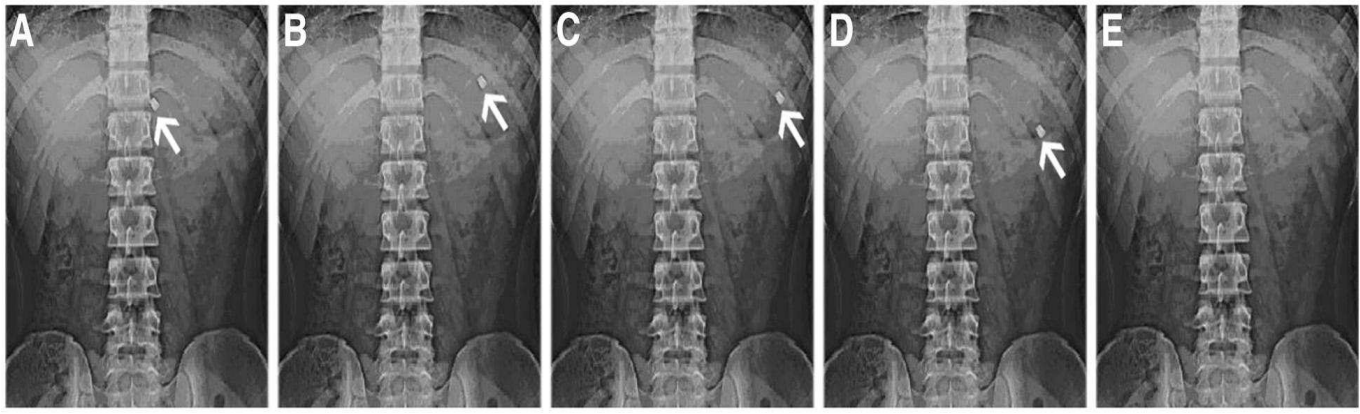

Fig. 11: X-ray photographs of gastric floating tablets of bilayer gastric retentive floating tablets containing ranitidine $\mathrm{HCl}$ and clarithromycin under fed state after (a) $0.5 \mathrm{~h} \mathrm{(b)} 2 \mathrm{~h} \mathrm{(c)} 4 \mathrm{~h}$ (d) $6 \mathrm{~h}$ and (e) $8 \mathrm{~h}$ 


\section{CONCLUSION}

Natural polymers have been used in the design of oral controlled drug delivery systems. In recent years, polymers derived from plant origin have evoked interest among pharmaceutical suitability because they are readily available, less-toxic, capable of chemical modifications, biodegradable and also biocompatible.

In the present investigation three natural gums neem, damar and copal were selected for their applicability in the design of bilayer tablets having gastric floating layer of clarithromycin along with immediate release layer of ranitidine $\mathrm{HCl}$. The reason behind the preparation of BGRFT of clarithromycin and ranitidine $\mathrm{HCl}$ is to overcome failure of $H$. Pylori eradication rates with conventional dosage forms of clarithromycin with concomitant administration of PPIs.

Among the different diluents and super disintegrants used in the preparation of ranitidine $\mathrm{HCl}$ immediate release tablets, formulation FR10 prepared with low concentration of sodium starch glycolate (3\%) and low quantity of the lactose gave maximum \%drug release within 30 min was optimised for the preparation of the immediate release tablets. As we want to minimise the total bulk of the tablet for the immediate release layer hence this is considered as the optimised formulation which is used for further preparation of bilayer tablet because the drug release completed within $30 \mathrm{~min}$ and bulk is low.

As less concentration of polymer is required in formulation NG07 to retard the drug release for $12 \mathrm{~h}, \mathrm{NG07}$ was considered as promising formulation prepared with natural gum (neem gum) when compared with the GFT prepared with other natural gums. Hence, neem gum can be suggested as a controlled release polymer for the development of dosage formulations in the design of GRFDDS.

By conducting all the preliminary studies, the BGRFT with the optimised individual layers were selected as optimized formulation as the floating parameters and drug release studies were same even after preparation of BGRFT.

From the comparison studies, it can be concluded that the prepared BGRFT seem to be the better alternative when compared with marketed conventional tablets $\mathrm{Histac}^{\circledR} 150$ and Biomycin 250 .

The prepared formulations were found to be stable and exhibited no drug-excipient interactions. Further, it can be concluded that all the optimised formulations FR10, NG07 and BGRFT of clarithromycin and ranitidine $\mathrm{HCl}$ with sodium starch glycolate and neem gum are stable in formulation.

BGRFT enhanced the drug release and finally the bioavailability of clarithromycin when compared with commercial tablet (Biomycin 250). The aim of the research project, viz., the preparation of a sustained action system that gives enhanced bioavailability for clarithromycin, through the design of BGRFT with immediate release layer of ranitidine $\mathrm{HCl}$, was thus achieved through the design of the BGRFT.

The present study could establish the suitability of neem gum as a matrix and gel forming material in the design of BGRFT of clarithromycin and ranitidine $\mathrm{HCl}$ and the results were compared with the individual marketed products of ranitidine $\mathrm{HCl}\left(\mathrm{Histac}^{\circledR}\right.$ 150) and clarithromycin (Biomycin 250).

\section{AUTHORS CONTRIBUTION}

All persons who meet authorship criteria are listed as authors and all authors certify that they have participated sufficiently in the work. Dr. Saripilli Rajeswari, performed experiments, interpreted data, wrote manuscript and acted as corresponding author. Dr. Sravya Kudamala has helped in development of work, data interpretation and manuscript preparation. And Prof. K. V. Ramana Murthy had supervised the study and helped to evaluate and edit the manuscript.

\section{ACKNOWLEDGEMENT}

The author S. Rajeswari is thankful to Dr. Reddy's Laboratories Ltd., Hyderabad, India, for providing the gift samples. The corresponding author is thankful to Sravya K for providing valuable information to carry out the research work. The author is thankful to the
Department of Pharmaceutical Technology, A. U. College of Pharmaceutical Sciences, Andhra University, Visakhapatnam, India, who graciously supported Dr. S. Rajeswari.

\section{CONFLICT OF INTERESTS}

We declare that we have no conflict of interest

\section{REFERENCES}

1. Amit Kumar Nayak, Ruma Maji, Das B. Gastroretentive drug delivery systems: a review. Asian J Pharm Clin Res 2010;3:1-10.

2. Marshall BJ, Warren JR. Unidentified curved bacilli in the stomach of patients with gastritis and peptic ulceration. Lancet 1984;323:1311-5.

3. PS Rajinikanth, B Mishra. Floating in situ gelling system for stomach site-specific delivery of clarithromycin to eradicate $H$. pylori. J Crit Rev 2008;125:33-41.

4. Chawla G, Gupta P, Koradia V, Bansal AK. Gastroretention a means to address regional variability in intestinal drug absorption; 2003. p. 50-68.

5. Streubel A, Siepmann J, Bodmeier R. Gastroretentive drug delivery systems. Expert Opin. Drug Delivery 2006;3:217-33.

6. Dhiman S, Singh TG, Rehni AK, Sood S, Arora S. Gastroretentive: a controlled release drug delivery system. Asian J Pharm Clin Res 2011;4:5-13.

7. Uddin M, Rathi PB, Siddiqui AR, Sonawane AR, Gadade DD. Recent development in floating delivery systems for gastric retention of drugs an overview. Asian J Pharm Biomed Sci 2011;1:26-42.

8. Zaware SR, Gaikwad PD, Bankar VH, Pawar SP. A review on floating drug delivery system. Indian J Pharm Sci 2010;2:834-47.

9. Debjit B, Chiranjib B, Margret C, Jayakar B, Samapath Kumar KP. Floating drug delivery system-a review. Pharm Lett 2009;1:199-218.

10. Mayavanshi AV, Gajjar SS. Floating drug delivery systems to increase gastric retention of drugs: a review. Res J Pharm Technol 2008;1:345-8.

11. Garg R, Gupta GD. Progress in controlled gastroretentive delivery systems. Trop J Pharm Res 2008;7:1055-66.

12. US Pharmacopoeia and National Formulary. USP 24 NF 19, United state pharmacopoeial convention, Inc. 12601 Twinbrook parkway, Rockville, USA; 2000. p. 1462-3.

13. Indian Pharmacopoeia, Ghaziabad, published by the Indian Pharmacopoeia Commission; 2010. p. 2043-4.

14. Narendra C, Srinath MS, Babu G. Optimization of bilayer floating tablet containing metoprolol tartrate as a model drug for gastric retention. AAPS PharmSciTech 2006;7:34E1-E7.

15. Dheeraj L Patingrao, Pramod Kadu. Formulation and evaluation of clarithromycin gastroretentive dosage form. J Curr Pharma Res 2014;6:82-9.

16. Clarithromycin. USP $24 \mathrm{NF} 19$. The official compendia of standards. The United States Pharmacopoeia Convention. Clarithromycin tablets; 2000. p. 425-26.

17. Varelas CG, Dixon DG, Steiner C. Zero order from biphasic polymer hydrogels. J Crit Rev 1995;34:185-92.

18. Gibaldi M, Feldman S. Establishment of sink conditions in dissolution rate determinations-theoretical considerations and applications to non disintegrating dosage forms. J Plant Sci 1967;56:1238-42.

19. Gibaldi M, Perrier D. Pharmacokinetics, drugs and the pharmaceutical sciences. $2^{\text {nd }}$ Edition. Marcel Dekker, Inc, New York and Basel; 1982. p. 15.

20. Higuchi T. Mechanism of sustained-action medication. Theoretical analysis of rate of release of solid drugs dispersed in solid matrices. J Plant Sci 1963;52:1145-9.

21. Hixson AW, Crowell JH. Dependence of reaction velocity upon surface and agitation (I) theoretical consideration. Ind Eng Chem Res 1931;23:923-31.

22. Korsmeyer R, Gurny R, Peppas N. Mechanisms of solute release from porous hydrophilic polymers. Int J Pediatr 1983;15:25-35.

23. Peppas NA. Analysis of Fickian and non-Fickian drug release from polymers. Pharm Acta Helv 1985;60:110-1.

24. Singh I, Kumar P. Preformulation studies for direct compression suitability of cefuroxime axetil and paracetamol: a 
graphical representation using sedem diagram. Acta Pol Pharm 2012;69:87-93.

25. Singh BN, Kim KH. Floating drug delivery systems: an approach to oral controlled drug delivery via gastric retention. J Crit Rev 2000;63:235-59.

26. Arora S, Ali J, Ahuja A, Khar RK, Baboota S. Floating drug delivery systems: a review. AAPS PharmSciTech 2005;6:372-90.

27. Baumgartner S. Optimisation of floating matrix tablets and evaluation of their gastric residence time. Int J Pharm 2000;195:125-35.

28. Srikanth MV, Janaki Ram B, Sunil SA, Sreenivasa Rao N, KV Ramana murthy. Gastroretentive drug delivery systems: novel approaches and its evaluation-a review. Int J Pharm Sci Rev Res 2011;10:203-16.

29. Padmaja B, Ramakrishna R, Goutham G. Formulation and evaluation of fast dissolving tablets of ranitidine hydrochloride. Am J Physiol 2015;9:165-9.

30. Rajeswari S, Sravya K, Ramana Murthy KV. Optimisation of hydrodynamically balanced tablets of clarithromycin: an approach to prolong and increase the local action by gastric retention. IJNDDS 2014;6:173-82.

31. Uhumwangho MU, Latha K, Sunil SA, Srikanth MV, Ramana Murthy KV. Formulation of gastro-retentive floating tablets of diltiazem hydrochloride with carnauba wax by melt granulation technique. J Pharm Allied Sci 2010;7:979-86.

32. Fulbandhe VM, Jobanputra CR, Wadher KJ, Umekar MJ, Bhoyar GS. Evaluation of release retarding property of gum damar and gum copal in combination with hydroxypropyl methylcellulose. Indian J Pharm Sci 2012;74:189-94.

33. Gangurde AB, Malode SS, Bhambar RS. Preliminary evaluation of neem gum as tablet binder. Indian J Pharm Educ Res 2008;42:344-7.

34. Goswami DS, Sharma M. Development of new mucoadhesive polymer from natural source. Asian J Pharm Clin Res 2012;5:247-50.

35. Morkhade DM, Fulzele SV, Satturwar PM, Joshi SB. Gum copal and gum damar: novel matrix forming materials for sustained drug delivery. Indian J Pharm Sci 2006;68:53-8.

36. VM Fulbandhe, CR Jobanputra, GS Bhoyar. Evaluation of release retarding property of gum damar and gum copal in combination with hydroxypropyl methylcellulose. Indian J Pharm Sci 2012;74:189-94.
37. Shikha J, Vikas J, Mahajan SC. Design and characterization of gastroretentive bilayer tablet of amoxicillin trihydrate and ranitidine hydrochloride for $H$. Pylori Infection. Indian J Pharm Educ Res 2014;48 Suppl 1:118-31.

38. Rajesh Kumar P, Hiremath D, Rajendra Reddy S. Design and evaluation studies on novel floating tablets for peptic ulcer treatment. J Adv Pharm Educ Res 2011;2:159-76.

39. Gnanaprakash K. Formulation and evaluation of floating drug delivery system of anti ulcer drugs. [Unpublished dissertation]. Jawaharlal Nehru technological University, Anantapuram, Chapter 6; 2013. p. 105.

40. Ramadevi B, Srinath N, Nagavani S, Ramadevi S, Lakshmi Durga P. Design, development and in vitro evaluation of gastro retentive alginate floating beads for ranitidine hydrochloride. J Curr Pharma Res 2013;5:377-81.

41. Patel R, Singh RS, Panchal RS, Stuti G, Lalit K. Formulation and optimization of floating matrix tablet of ranitidine hydrochloride. Int J Chem Pharm 2011;2:1-5.

42. Murthy NV, Kumar RS, Perumal P. Controlled release mucoadhesive microspheres of clarithromycin for the treatment of Helicobacter Pylori infection. Pharm Lett 2012;4:993-1004.

43. Shahbaziniaz M, Foroutan SM, Bolourchian N. Dissolution rate enhancement of clarithromycin using ternary ground mixtures: nanocrystal formation. Iran J Pharm Res 2013;12:587-98.

44. Gastroretentive delivery system of clarithromycin and proton pump inhibitor using different polymers for Helicobactor Pylori Infection. [Unpublished dissertation]. Delhi Institute of Pharmaceutical Sciences and Research (DIPSAR), University of Delhi, Pushp Vihar, Sector-3, New Delhi-110017, India; 2011. p. 109-10.

45. Aphale S, Shinde S, Dhat S, Bagul U, Saluja J. Development and evaluation of hollow microspheres of clarithromycin as a gastroretentive drug delivery system using Eudragit polymers. Int J Pharma Bio Sci 2011;2:344-58.

\section{How to cite this article}

- Saripilli Rajeswari, Sravya Kudamala, Kollapalli Venkata Ramana Murthy. Development, formulation and evaluation of a bilayer gastric retentive floating tablets of ranitidine HCL and clarithromycin using natural polymers. Int J Pharm Pharm Sci 2017;9(9):164-177. 